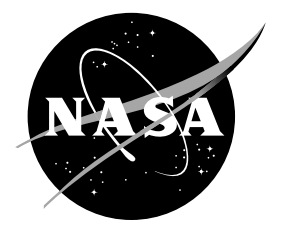

\title{
Energy Efficient Engine Low Pressure Subsystem Aerodynamic Analysis
}

Edward J. Hall, Robert A. Delaney, and Sean R. Lynn

Allison Engine Company, Indianapolis, Indiana

Joseph P. Veres

Lewis Research Center, Cleveland, Ohio 
Since its founding, NASA has been dedicated to the advancement of aeronautics and space science. The NASA Scientific and Technical Information (STI) Program Office plays a key part in helping NASA maintain this important role.

The NASA STI Program Office is operated by Langley Research Center, the Lead Center for NASA's scientific and technical information. The NASA STI Program Office provides access to the NASA STI Database, the largest collection of aeronautical and space science STI in the world. The Program Office is also NASA's institutional mechanism for disseminating the results of its research and development activities. These results are published by NASA in the NASA STI Report Series, which includes the following report types:

- TECHNICAL PUBLICATION. Reports of completed research or a major significant phase of research that present the results of NASA programs and include extensive data or theoretical analysis. Includes compilations of significant scientific and technical data and information deemed to be of continuing reference value. NASA's counterpart of peerreviewed formal professional papers but has less stringent limitations on manuscript length and extent of graphic presentations.

- TECHNICAL MEMORANDUM. Scientific and technical findings that are preliminary or of specialized interest, e.g., quick release reports, working papers, and bibliographies that contain minimal annotation. Does not contain extensive analysis.

- CONTRACTOR REPORT. Scientific and technical findings by NASA-sponsored contractors and grantees.
- CONFERENCE PUBLICATION. Collected papers from scientific and technical conferences, symposia, seminars, or other meetings sponsored or cosponsored by NASA.

- SPECIAL PUBLICATION. Scientific, technical, or historical information from NASA programs, projects, and missions, often concerned with subjects having substantial public interest.

- TECHNICAL TRANSLATION. Englishlanguage translations of foreign scientific and technical material pertinent to NASA's mission.

Specialized services that complement the STI Program Office's diverse offerings include creating custom thesauri, building customized data bases, organizing and publishing research results ... even providing videos.

For more information about the NASA STI Program Office, see the following:

- Access the NASA STI Program Home Page at http://www.sti.nasa.gov

- E-mail your question via the Internet to help@sti.nasa.gov

- Fax your question to the NASA Access Help Desk at (301) 621-0134

- Telephone the NASA Access Help Desk at (301) 621-0390

- Write to:

NASA Access Help Desk

NASA Center for AeroSpace Information 7121 Standard Drive

Hanover, MD 21076 
NASA/TM-1998-208402

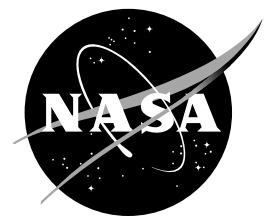

\section{Energy Efficient Engine Low Pressure Subsystem Aerodynamic Analysis}

Edward J. Hall, Robert A. Delaney, and Sean R. Lynn

Allison Engine Company, Indianapolis, Indiana

Joseph P. Veres

Lewis Research Center, Cleveland, Ohio

Prepared for the

34th Joint Propulsion Conference and Exhibit

cosponsored by AIAA, ASME, SAE, and ASEE

Cleveland, Ohio, July 13-15, 1998

National Aeronautics and

Space Administration

Lewis Research Center 


\section{Acknowledgments}

The work described in this paper was supported under the NASA High Performance Computing and Communication Program (HPCCP), contract NAS3-27394, Task 13.

Available from

NASA Center for Aerospace Information 7121 Standard Drive

Hanover, MD 21076

Price Code: A03
National Technical Information Service 5287 Port Royal Road Springfield, VA 22100 Price Code: A03 


\title{
Energy Efficient Engine \\ Low Pressure Subsystem \\ Aerodynamic Analysis
}

\author{
Edward J. Hall* \\ Robert A. Delaney ${ }^{\dagger}$ \\ Sean R. Lynn ${ }^{\ddagger}$ \\ Allison Engine Company, Indianapolis, IN 46241 \\ Joseph P. Veres ${ }^{\S}$ \\ NASA Lewis Research Center, Cleveland, $\mathrm{OH} 44135$
}

\begin{abstract}
The objective of this study was to demonstrate the capability to analyze the aerodynamic performance of the complete low pressure subsystem (LPS) of the Energy Efficient Engine (EEE). Detailed analyses were performed using three-dimensional Navier-Stokes numerical models employing advanced clustered processor computing platforms. The analysis evaluates the impact of steady aerodynamic interaction effects between the components of the LPS at design and off-design operating conditions. Mechanical coupling is provided by adjusting the rotational speed of common shaft-mounted components until a power balance is achieved. The Navier-Stokes modeling of the complete low pressure subsystem provides critical knowledge of component aero/mechanical interactions that previously were unknown to the designer until after hardware testing.
\end{abstract}

\begin{tabular}{|c|c|c|c|}
\hline \multicolumn{2}{|r|}{ Nomenclature } & \multirow{2}{*}{$\begin{array}{l}c_{0} \\
\text { rpm }\end{array}$} & \multirow{2}{*}{$\begin{array}{l}\text { Spced of sound } \\
\text { Revolutions per minute }\end{array}$} \\
\hline A & 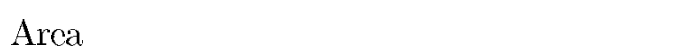 & & \\
\hline Atotal & Total arca & $u$ & \\
\hline$A D P A C$ & Advancod Ductcd Propfan Analysis Code & $x, r, \theta$ & cylindrical body axcs \\
\hline$B P R$ & Bypass ratio & $x, y, z$ & Cartesian body axcs \\
\hline$C A S$ & Computational AcroScicnces & $\rho$ & Density, $\mathrm{kg} / \mathrm{m}^{3}$ \\
\hline $\mathrm{Cl}$ & Climb & \multicolumn{2}{|c|}{ Subscripts } \\
\hline$C F D$ & Computational Fluid Dynamics & exit & exit value \\
\hline $\mathrm{Cr}$ & Cruisc & inlet & inlet valuc \\
\hline$E E E$ & Encrgy Efficient Engine & $s$ & static quantity \\
\hline$L E$ & $\begin{array}{l}\text { Lcading Edgc } \\
\text { Low Pressure }\end{array}$ & $t$ & total (stagnation) quantity \\
\hline $\begin{array}{l}L P \\
L P S\end{array}$ & $\begin{array}{l}\text { Low Pressure } \\
\text { Low Pressure Subsystem }\end{array}$ & & \\
\hline$H P$ & High Pressure & & Introduction \\
\hline$N$ & Corrected Specd & & ETITIVE market conditions in the gas tur- \\
\hline NPSS & Numcrical Propulsion System Simulation & & industry have placed stringent demands on \\
\hline$O / L$ & Operating line & cngine & anufacturers to respond to customer require- \\
\hline$P$ & Pressurc, psia & ments & th officient, cost effoctive products with sig- \\
\hline$S L S$ & Sca lcvel static & nifican & reductions in development time. During the \\
\hline$T$ & Tempcrature, degrces R & cngine & cvelopment period, component efficiencies of- \\
\hline$T E$ & Trailing Edgc & ten fal & hort of desired goals by significant margins. \\
\hline & Vclocity, ft/s & The on & ne cycle rebalance which results causes other \\
\hline $\begin{array}{l}{ }^{*} \text { Staff R } \\
\text { Member A } \\
\text { 'Chief, } \\
\text { AIAA } \\
\text { †Advan } \\
\text { \$YManag } \\
\text { Systems O } \\
\text { This p } \\
\text { Subject to }\end{array}$ & $\begin{array}{l}\text { Iesearch Scientist, Advanced Turbomachinery Dept., } \\
\text { IAA } \\
\text { Advanced Turbomachinery Dept., Senior Member } \\
\text { ced Turbomachinery Dept., Member AIAA } \\
\text { er, Engine Systems, Computer and Interdisciplinary } \\
\text { ffice, Member AIAA } \\
\text { aper is a work of the L.S. Government and is not } \\
\text { copyright protection in the Lnited States. }\end{array}$ & $\begin{array}{l}\text { com } \\
\text { con } \\
\text { ing } \\
\text { cicn } \\
\text { sent } \\
\text { cost } \\
\text { pon } \\
\text { desi }\end{array}$ & $\begin{array}{l}\text { nts to operate at non-optimal (oft-design) } \\
\text { s, further reducing efficiency and complicat- } \\
\text { dentification of the original source of incff- } \\
\text { Expensive, multiple build rig testing, repre- } \\
\text { major portion of the overall development } \\
\text { in the past, becn required to balance com- } \\
\text { crformance and optimize the engine system }\end{array}$ \\
\hline
\end{tabular}


Efforts to attack the problems associated with aircraft gas turbine engine devclopment have becn addressed through scveral NASA Programs. The Advanced Subsonic Technology (AST) Program specifically supports technology development to improve the performance of subsonic aircraft, both in flight characteristics and propulsion. The High Performance Computing and Communication (HPCC) Program and more specifically, the Computational Acrosciences (CAS) Project are directed to accelcrate the availability of high performance computing tochnology for use by the U.S. acrospace community. A "Grand Challenge" application under the HPCCP is the high fidelity, interdisciplinary simulation of a full propulsion system, called the Numcrical Propulsion System Simulation (NPSS).

Component design tcams depend on numerical analysis techniques to achicve the best performance. Strcamline curvature methods continue to be cxtcnsively used to analyze multistage turbomachinery. More recently, the trend has been to apply advanecd 2-D and 3-D numcrical techniques ${ }^{1}$ to engine components to understand the details of their operation in isolation. Multistage analyses for turbomachincry are also becoming increasingly more valuable, ${ }^{2}{ }^{3}$

These advanced component analysis techniques often do not systcmatically account for inter-component interactions. Multistage analyses may someday provide adcquate representation of interaction effects between blade rows in an axial compressor, for cxample, but do not presently provide information related to inter-component interactions (HP/LP turbine systems, c.g.). This paper describes efforts directed at creating a system which will allow individual component models to be coupled to create a full engine simulation.

\section{Energy Efficient Engine}

In 1976 NASA initiated the Aircraft Encrgy Efficiency (ACEE) Program to assist in the devclopment of technology for more fucl-efficient aircraft for commercial airline use. The Energy Efficient Engine (EEE) Project of the ACEE Program was intended to lay the advanced technology foundation for a now gencration of turbofan engines. This seven-ycar coopcrative government-industry effort, was aimed at devcloping and demonstrating advancod component and systems technologies for engines that could be introduced into airline scrvice by the late 1980 's or carly 1990 's. Under the EEE Program, both isolated component and engine rig tests were performed based on a demonstrator engine developed by the General Electric Corporation, which has since come to be known simply as the Encrgy Efficient Engine (all further references in this document for EEE shall refor to the engine, not the ACEE EEE Program, per se). The EEE provides a natural vchicle for the type of large scale simulation devcloped for this study due to the availability of both subcomponent test rig data, as woll as fully coupled, asscmbled engine test data.

\section{Objectives of this Study}

The overall objective of this project is to provide the capability to analyze the acrodynamic performance in the complete low pressure subsystem (LPS) of the Encrgy Efficient Engine (EEE) using threc-dimensional Navicr-Stokes numerical models. The analysis cvaluates the impact of stcady acrodynamic interaction offects between the components of the LPS at the design and at off-design opcrating conditions. The approach for crcating the LPS model was to select a validated Navicr-Stokes (N-S) analysis code, and create the EEE LPS model from the geometric components in the LPS including: extcrnal flow, nacelle, inlet, fan blades, bifurcated bypass and core inlet, bypass vanes, core inlet guide vanes, quarter height booster stage, low pressure turbine blades, mixer, and cxhaust nozzle. Engine core components were modeled using appropriate boundary conditions derived from test data and an engine cycle performance deck. The N-S analysis of the fully coupled LPS cnables a torque balance on the low pressure spool at quasi-stcady state opcrating conditions.

This study was divided into five major milestone arcas:

- Geometry Definition: Detailed gcometry definitions of the components of the Encrgy Efficient Engine primary gas flowpaths wore asscmbled.

- Mesh Generation: Gcometry definitions described above were employcd to develop discrete mesh systems suitable for CFD analysis.

- Component Validation Study: Block components of the LP and HP subsystems wore analyzed using CFD tools to verify the accuracy of the gcometry definitions, and to validate the CFD analysis with available rig test data.

- LP Subsystem Analysis: Various components were assembled to form the discrete representation of the LP Subsystem, and a quasi-stcady CFD analysis was applicd to predict both the acrodynamic and mechanical coupling of the LP Subsystem.

- Core Cycle Specification: An cngine cycle performance model was coupled with the 3-D CFD analysis to represent the operating parameters for the engine core in the LP Subsystem Analysis.

Each of the five milestone topies are described in more detail in the scetions which follow. The ultimate objective of this study was to develop a simulation capability for the LP Subsystem of modern high bypass 


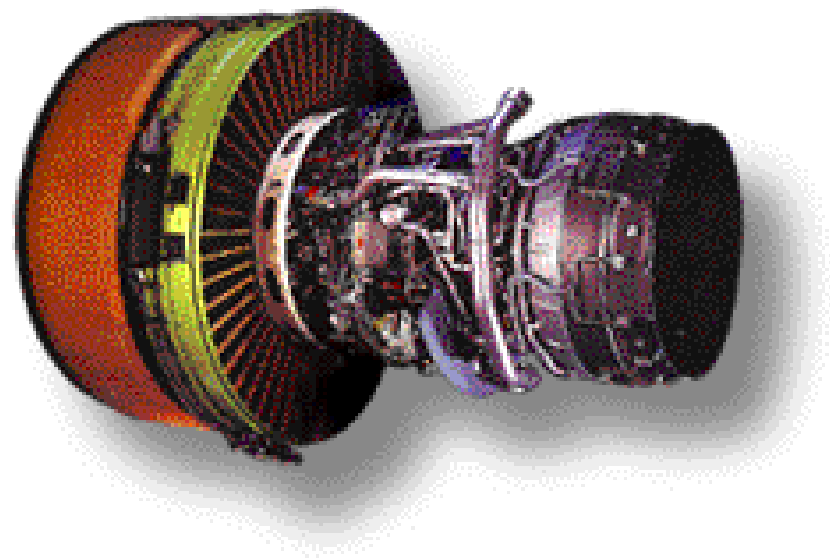

Fig. 1 Energy Efficient Engine test rig hardware.

ratio turbofan engines which would address the goals of the NASA NPSS Program.

\section{Geometry}

Detailcd gcomctry for the EEE modcl was cxtracted from the NASA Encrgy Efficient Engine Mastcr Gcomctry Databasc. This databasc was devcloped spccifically for NPSS-rclated applications which employ the EEE design for demonstration. The database consists of NASA IGES curve-based and surface-based entities describing the major components of the engine core and bypass gas flowpaths. Exact geometric definitions of the EEE LPS are cmployed, with the cxception of the outer nacclle and inlet, which have been designed consistent with the Energy Efficient Engine design philosophy in order to take the place of the test rig bellmouth. A picture of the Encrgy Efficient Engine test rig hardware is given in Figure 1.

\section{NEPP Cycle Analysis}

One facet of the analyses performed during this study was the desire to investigate aspects of the "zooming" feature of the planned NPSS engine performance analysis architccture. In this regard, the intention was to numcrically couple detailed CFD simulations of the EEE LP spool with an engine cycle analysis of the EEE HP corc. This coupled simulation, would, in fact, be a complete simulation of the two-spool EEE cngine with varying lcvels of fidelity for the LP and HP subsystems. The ADPAC analysis was dircetcd at the 3-D CFD portion of this simulation stratcgy, while the NEPP 1-D cyclc analysis was directed at the HP spool simulation stratcgy.

The NEPP computer program ${ }^{1}$ performs oncdimensional, stcady-state thermodynamic performance analysis of aircraft gas turbine or jet engine configurations. Data inputs specify a standard set of components and their interconnections, allowing simulation of virtually any cngine configuration. Physical components which may be used include propellers, inlets, ducts, combustors, fans, compressors, turbines, shafts, heat cxchangers, flow splitters, subsonic mixcrs and/or supersonic cjectors, nozzles and water injectors or gas gencrators.

There are scveral steps for putting together a NEPP input file to analyze an engine systcm.

- Select the engine cycle.

- Convert the cycle into a block diagram for NEPP.

- Define the compressor and turbine performance maps. Exact maps for the application are not required, the program can scale maps as required.

\section{ADPAC Code Description}

The acrodynamic predictions for the cases described in this study wcre obtaincd using the $A D P A C$ analysis code. The $A D P A C$ code is a gencral purpose acrospace propulsion acrodynamic analysis tool which has undcrgone cxtensive devclopment, testing, and verification. ${ }^{5}$ Detailed code documentation is also available for the $A D P A C$ program.$^{6}$

The ADPAC analysis solves a time-dependent form of the three-dimensional Reynolds-averaged NavicrStokes cquations using a proven time-marching numerical formulation. The numcrical algorithm cmploys robust numerics based on a finite-volume, $\mathrm{cx}$ plicit Runge-Kutta time-marching solution algorithm derived from the devclopmental efforts of Jameson et al. ${ }^{7}$ Adamczyk ct al., ${ }^{8}$ and Arnone et al. ${ }^{9}$ Several stcady-state convergence accolcration tochniques (local time stepping, implicit residual smoothing, and multigrid) are available to improve the ovcrall computational efficiency of the analysis. A relativcly standard implementation of the Baldwin and Lomax ${ }^{10}$ turbulcnce model with wall functions was cmployed to compute the turbulent shear stresses and turbulent heat flux.

The ADPAC code permits the use of a multipleblocked mesh discretization which provides extreme flexibility for analyzing complex geometrics. The block gridding technique enables the coupling of complex, multiple-region domains with common (nonovcrlapping) grid interface boundaries through spccialized uscr-specificd boundary condition procedures.

$A D P A C$ supports coarse-graincd computational parallelism via block boundary-specificd message passing. Interprocessor communication is controlled by the Message Passing Interface (MPI) ${ }^{11}$ communication protocol. Both scrial and parallel computations were cmployed during this study utilizing a wide range of high specd processors, workstation clusters, and massivcly parallcl computing platforms, depcnding on availability.

Stcady-statc acrodynamic predictions for multistagc turbomachinery are performed using a specialized boundary procedure known as a "mixing plane". 2 The 
mixing plane strategy was devcloped to permit numerical simulations bascd on only a single blade passage representation for cach blade row, regardless of the differences in circumferential spacing for cach blade row. This simplification is afforded by circumferentially avcraging data on cither side of the interface between blade rows (the mixing plane), and then passing that information as a boundary condition to the ncighboring blade row.

\section{Mesh Generation}

Numcrous meshing strategies are possible with the $A D P A C$ code, the simplest of which is simply to use a single sheared H-type mesh for cach blade row (sce c.g. ${ }^{2}$. This meshing strategy also has the direct benefit that the resulting mesh could also be used for other NPSS-rclated multistage turbomachincry flow analyses. A key clement of the meshing strategy in this project was to employ the Master Engine Goometry Database IGES entities directly in the grid gencration process. Many mesh gencration codes require discretized point data as input to define the gcometry of interest. This discretized definition, and the subscquent interpolations which occur during the mesh gencration process can lead to crrors in the coordinates of the final mesh. One focus of the NPSS gcometry definition has becn to cmploy analytical definitions of geometric components in the form of IGES or NURBS-based cntitics. These analytical definitions would then form a consistent gcometric database for all disciplines (acrodynamic, stress, heat transfer, ctc.) and significantly reduce crrors duc to interpolations and interpretations of discrete point data. In order to address the mesh objectives described above, a procodure to gencrate meshes for the EEE LPS analysis directly from the NASA Encrgy Efficient Engine Mastor Engine Gcometry Database was devcloped and is described in the paragraphs below.

The construction of the numcrical mesh system for cach individual component is performed in a manner which permits a simple coupling of the component meshes for the complete LPS analysis. H-type computational meshes are cmployed for this purpose, although the analysis need not be limited in this fashion. A primary focus of the NPSS rescarch is to cmploy a consistent geometry definition during all phases of the cngine analysis. As such, a mesh gencration strategy was devcloped whose only dircet gcometric input is the NASA-IGES bascd geometry of the Master Engine Gcometry Database. A graphical illustration of the mechanies of the mesh gencration procedure is given in Figure 2.

The procedure is initiated by defining the exact geometric axial extents of the blade elements in the axisymmetric projection of the flowpath. This procedure was accomplished by interrogating the geometric clements for cach individual blade row, and cxtract-

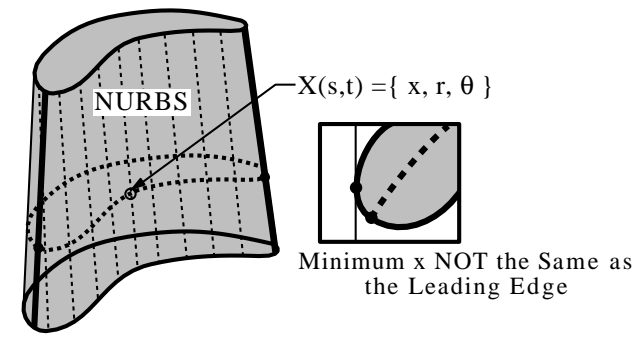

(1)

Identify radial profiles of $\mathrm{x}_{\mathrm{MIN}}$ and $\mathrm{x}_{\mathrm{MAX}}$ from NURBS surface.

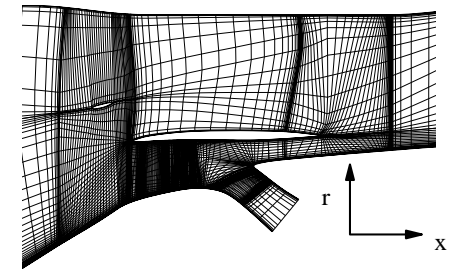

(2)

Use $\mathrm{x}_{\mathrm{MIN}}$ and $\mathrm{x}_{\text {MAX }}$ profiles to create meridional $(\mathrm{x}, \mathrm{r})$ point distribution (GRIDGEN)

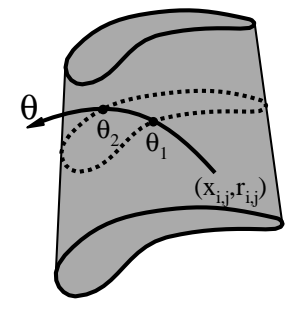

(3)

Sweep constant $(x, r)$ points through NURBS to determine $\theta$ 's. Every point satisfies NURBS equation.

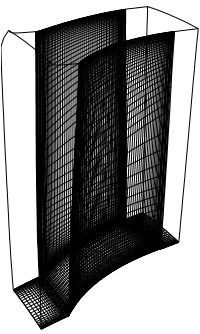

(4)

Distribute points across pitch of blade holding constant near-wall spacing.

Fig. 2 Component mesh generation procedure for EEE LPS analysis.

ing the geometric leading and trailing cdge outlines (in this scnse, the geometric leading and trailing edges are represented by the minimum and maximum axial coordinate locations, respectivcly). In essence, the radial profiles of the blade minimum and maximum axial coordinates were extracted from the blade IGES surface definition. These new entitics are themselves represented in GRIDGEN database scgment format and are added to the geometry database.

Once the blade row extents are defined, standard NASA-IGES capable mesh gencration schemes 
(GRIDGEN ${ }^{12}$ was uscd for this cxcrcisc) can be cmploycd to define the meridional projection of the $\mathrm{H}$ type meshes. The blade lcading and trailing cdge clements define the positions of the blade rows in the axisymmetric projection, while the Master Engine Geometry Database flowpath definitions define the endwalls. The GRIDGEN program (which can read in the IGES cntities as a geometry database) is then used to define the axial $(x)$ and radial $(r)$ point distributions in the meridional projection. Typical mesh dimensions for the axisymmetric components of the meshes cmployed 49 points radially along the blade span, and 65 points axially along the chord of the blade.

Next, the $(x, r)$ coordinate pairs from the meridional mesh projection are swept through the airfoil IGES surface definition to detcrmine the blade surface circumferential $(\theta)$ point distributions. The remaining points in the circumferential dircetion (betwecn airfoils) are defined using a simple hyperbolic distribution routine (sce c.g. ${ }^{13}$ ). The circumferential distributions were constructed to maintain a fixcd, specificd near wall spacing in the circumferential direction. Most of the mesh gencration procedure is automated, though some hand construction was unavoidable. A complete mesh for a compressor or turbine subcomponent, for cxample, gencrally required 4 hours to completc.

\section{Component Validation Study}

Component performance validation was considered a necessary milestone both in validating the accuracy of the analysis as well as verifying the accuracy of the gcometry specifications in the EEE Master Engine Geometry Databasc. During this phase of the program, specific subcomponent geometries were selected and analyzed in isolation from the other major subcomponents of the overall EEE LPS analysis.

\section{EEE Fan Section Analysis}

The EEE fan section design is based on a unique split flow configuration selected to minimize mission fucl burn and direct opcrating cost. An illustration of the EEE fan section flowpath and blade arrangement is given in Figure 3. The EEE fan section design cmploys a full span fan rotor with a design corrected tip spced of $1350 \mathrm{ft} / \mathrm{s}$. and an inlet radius ratio of 0.342 . The fan employs a part span shroud to improve structural rigidity. The fan rotor cxit flow is split radially by an island splitter. The inner annulus of this island splitter is designed to capture $22 \%$ of the fan flow and cmploys a 1/4-height booster stage. The 1/4-height boostcr stage further supcrcharges the flow entering the core and cnhances core protection from forcign object damage. The use of the booster stage also permits a lower fan rotational specd, increased fan cfficiency, lower fan hub acrodynamic loading, and provides for an casier engine growth path. The flow through the booster stage is subscquently split by the core inlet,

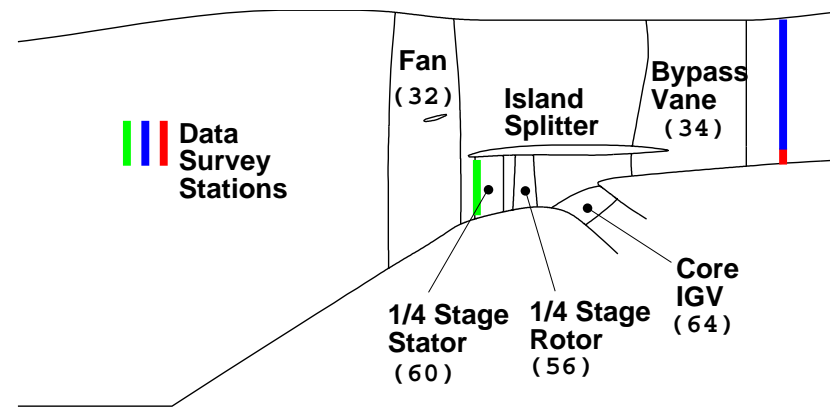

Fig. 3 Axisymmetric projection of EEE fan+1/4height booster stage configuration ilustrating test data instrumentation plane locations.

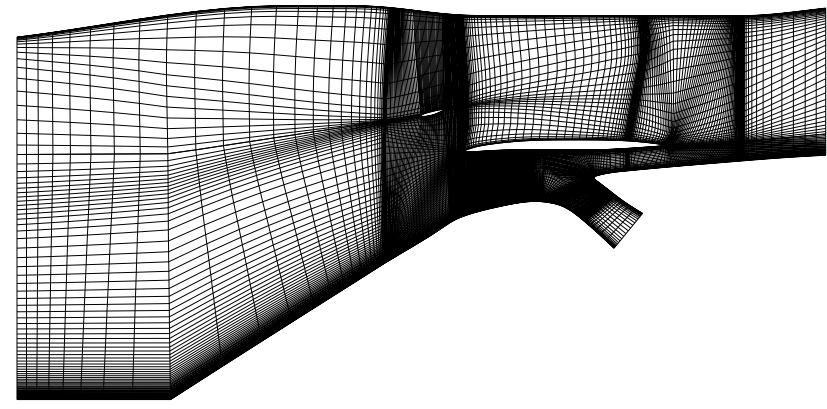

Fig. 4 Axisymmetric projection of EEE fan section multi-block H-type mesh system.

with $68 \%$ of the booster flow entering the core and the remaining $42 \%$ of the booster flow recntering the bypass flowpath through the bypass vane. The outer annulus flow carries the remaining $78 \%$ of the fan rotor flow through the bypass vanes. The analysis included the full height fan with part span shroud, 1/4-height booster stage, core inlet guide vane, and bypass vane as shown in Figure 3.

The mesh gencration procedure previously described was employed to define a $1,605,000$ coll mesh distributed among 8 mesh blocks. An illustration of the axisymmetric projection of the mesh system is given in Figure 4.

A design point analysis was performed for the EEE fan scetion using the mesh system described in the previous subsection. The EEE fan section design bypass ratio is 6.8 , and the fan design point represents the cngine maximum climb opcrating point. The analysis was performod on a 4-processor Silicon Graphics Powcr Challenge L multiprocessor computer with 1 GB of main memory. A converged solution was obtained in a total of 6 hours (wall clock time) using all four processors. Figure 5 illustrates the predicted fan surface static pressure contours from the analysis. Numerical predictions for the EEE fan section were compared with experimental data derived from full scale rig tests of the fan section. ${ }^{11}$ Figure 6 illustrates a comparison of predicted and experimental bypass vane cxit and 1/4-stage vane lcading cdge spanwise total pres- 


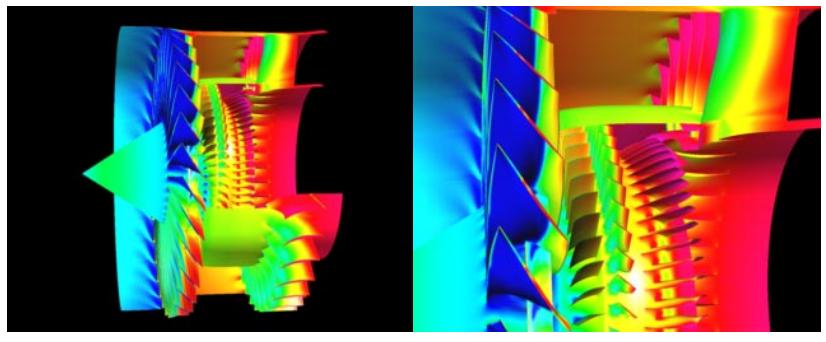

Fig. 5 Predicted surface static pressure contours for EEE fan plus 1/4-height booster stage configuration.

ADPAC EEE Fan + Quarter Stage Flow Prediction

Quarter Stage Stator and Bypass Vane Exit Spanwise Total Pressure Comparison

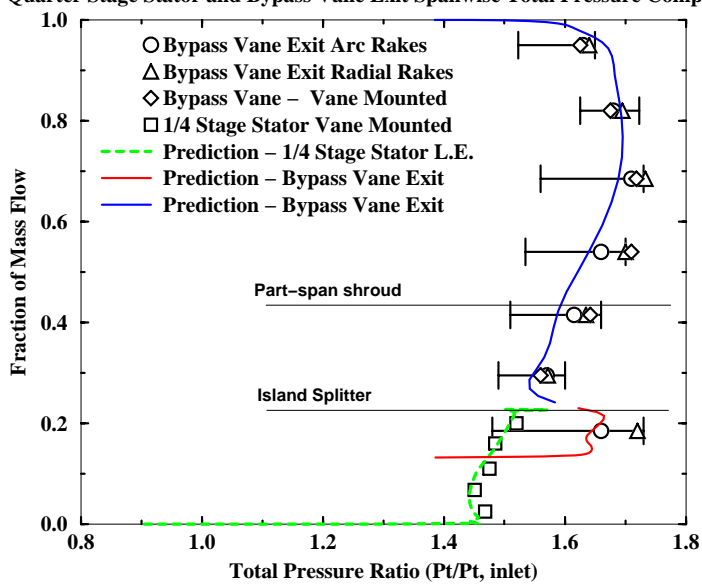

Fig. 6 Comparison of predicted and experimental spanwise total pressure distributions at bypass vane exit and 1/4-stage vane leading edge for EEE fan plus 1/4-height booster stage configuration.

sure distributions. The total pressure distributions are plotted and correlated with the colors of the data survey stations indicated on Figure 3. The character of the spanwise pressure distribution was very accurately captured, and was well within the range of the test data.

In order to investigate the off-design analysis capabilitics of the EEE fan scction model, a number of predictions were performed at $100 \%$ corrected specd with variations in both fan cxit static pressurc and fan section bypass ratio. These off-design results were obtained by prescribing the flow entering the core, and adjusting the bypass exit static pressure until the desired fan inlet flow was achicved. Excursions in predicted bypass ratio ranged from 6.0 to 10.8 .

Predictions of overall performance were compared with measured data derived from full-scale rig tests of the fan section. ${ }^{14}$ A comparison of predicted and cxpcrimental overall pressure ratio and adiabatic efficiency versus corrected mass flow rate for the core stream flow (downstream of the core inlet guide vane) of the EEE fan scction is given in Figure 7. The
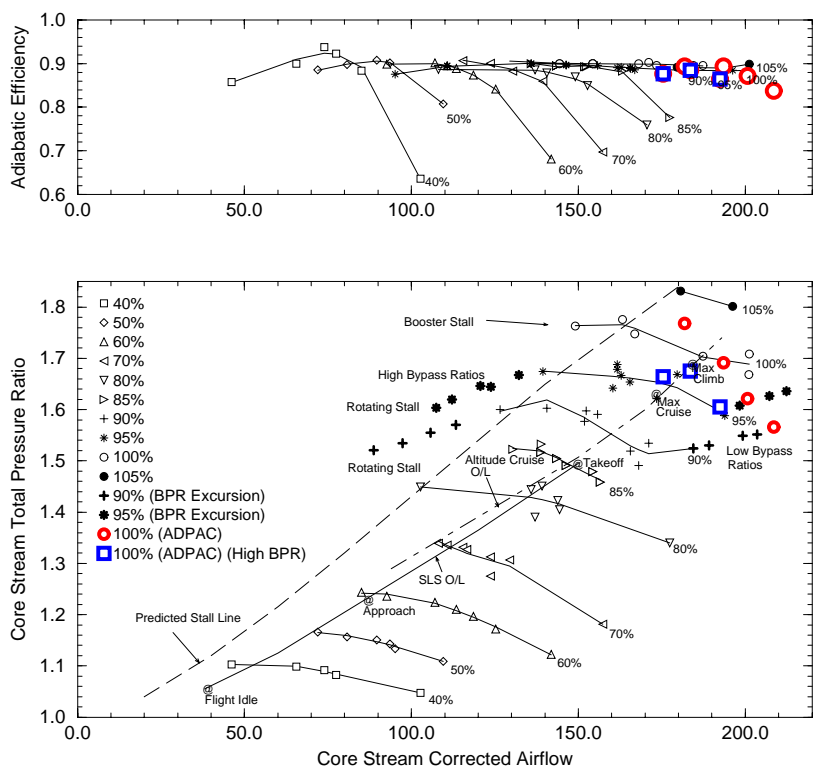

Fig. 7 Comparison of predicted and experimental total pressure ratio and adiabatic efficiency versus corrected flow rate for the core inlet of the EEE fan section.
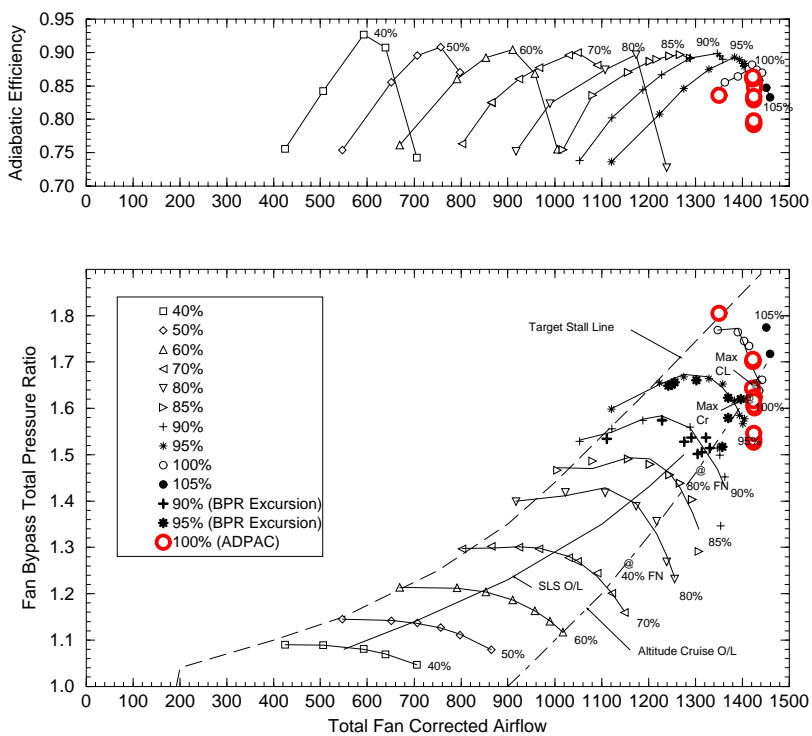

Fig. 8 Comparison of predicted and experimental total pressure ratio and adiabatic efficiency versus corrected flow rate for the bypass duct flow of the EEE fan section.

corresponding maps for the fan bypass stream flow (downstream of the fan bypass vane) is given in Figure 8. The data on these figures illustrates the overall capabilitics of the EEE fan design. Bold symbols on cach figure illustrate the test performance at extreme high and low values of bypass ratio. It is interesting to note that in both the test and the prediction, bypass ratio did not significantly alter the characteristics of the bypass stream, but does have a significant ef- 
fect on the core stream flow. The ovcrall character of the off-design performance predictions displayed good agrecment with the test data.

\section{EEE LP Turbine Analysis}

The EEE LP turbine consists of a 5-stage design cmploying moderatcly loaded airfoils and a rather high (25 degrees) endwall slope. The 5-stage design was bascd in part on results obtained from studies of highly loaded fan turbine technology development at Gencral Elcctric, and from system studics aimod at minimizing dircet opcrating cost (DOC). The EEE cngine LP turbine design is coupled to the HP turbine via a short (3 in.) transition duct. The relativcly high bypass ratio (6.8) of the EEE fan section, and subscquent reduced core flow requires high specific energy from the fan-drive (LP) turbine. The design efficiency goals for the LP turbine were $91.1 \%$ for the integrated core/low spool (ICLS) test and 91.7\% for the flight propulsion systcm (FPS) at the engine design point ( $\mathrm{M}=0.8$, $35,000 \mathrm{ft}$. altitude ISA). The LPT maximum tip diametcr was set by mechanical and configuration control requircments at $46.5 \mathrm{in}$. The outer wall slope was also limited to 25 degrees (established as a maximum to maintain good acrodynamic performance) through stage 3 , transitioning to a cylindrical outcr wall at the stage 5 cxit.

A mesh system consisting of 10 mesh blocks (1 per blade row for 5 stages) containing 1,660,000 computational colls was asscmbled.

Design point numcrical simulations of the EEE Low Pressure (LP) turbine were performed to permit comparison with $2 / 3$ scalc rig test data. ${ }^{15}$ The analysis was performed on a Silicon Graphics Powcr Challenge L multiprocessor computer with $1 \mathrm{~GB}$ of main momory. Converged solutions were obtaincd in a total of 3 hours (wall clock time) using four processors. Note that the turbine simulation was nearly twice as fast as the fan scetion simulation in spite of the fact that approximatcly $20 \%$ more mesh points were involved. This feature results from the gencrally favorable pressure gradients involved in the turbine flow, leading to a rapid definition of the boundary layer flow. Conversely, the fan section flow involves predominantly adverse pressure gradients requiring significantly more computation time to resolve. The rapid computation time for the turbine clearly indicates the suitability of the analysis for design cycle studics. In fact, more time was involved in gencrating suitable meshes than was involved in the acrodynamic analysis itsclf. Predicted turbine surface static pressure contours are illustrated in Figure 9. This figure illustrates the threc-dimensional nature of the blading and the general arrangement of the LP turbine.

A comparison of predicted and experimental spanwise variation of fifth stage cxit total pressure and total tempcrature profiles is given in Figure 10. This prelim-

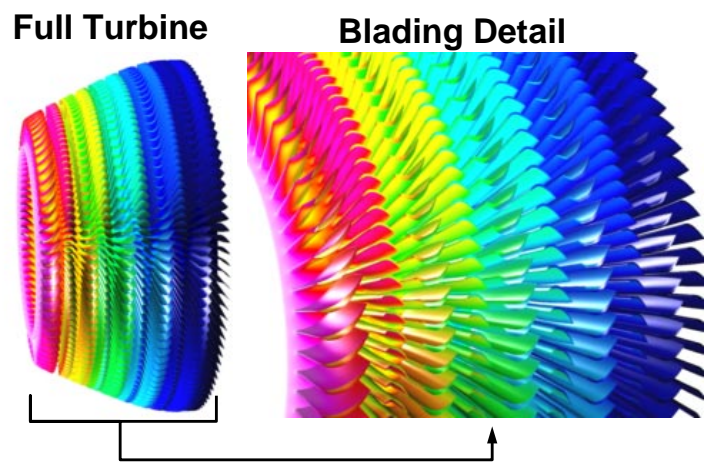

Fig. 9 Predicted surface static pressure contours for EEE LP turbine.

inary analysis was based on a simple flat inlet profile of total pressurc and total tempcrature and cmploycd the exact blade and endwall definitions provided in the original Master Engine Gcometry Database. The corrclation between rig test and calculation is excellent in the 20\%-80\% radial span region. Noticcable discrepancies exist in the near endwall regions. These discrepancies were assumed to be due to the fact that no clcarance flows, turbine hub overlap gcometry, or shroudcd rotor cavity gcometries were modeled in this initial prediction.

In order to resolve differences betwecn prediction and experiment near the endwalls, scveral additional calculations were performed to assess the effects of variations in geometry, flow parameters, etc. The variations tested included modifications to the first stage vane setting angle, modifications to the inlet flow profile, and the addition of a shrouded rotor endwall cavity model.

\section{Effect of Variations in First Vane Setting Angle}

GE engincers familiar with the actual test rig and EEE cngine geometry recommended a 1 degree (open) reset of the LP turbine first stage vane. The effect of the reset on the LP turbine exit spanwise flow profiles is illustrated on Figure 10. A distinct improvement in the predicted total temperature distribution was observed at the turbine exit, particularly near the tip, for the calculation involving the modificd gcometry. Given this obscrvation, all further calculations were based on the modified first stage vane orientation.

\section{Effect of Variations in Inlet Profile}

Scveral multistage calculations were performed with variations in the first vane input spanwise total pressure, total temperature, and flow angle profile distributions. The profiles are catcgorized as flat (bascline, esscntially no variation across the span except at the tip), boundary layer (BL - 5\%/10\% (hub/casc) thick total pressure deficit at the endwalls), and engine (derived from a simulation of the HP turbine cxit flow). An illustration of the spanwise variation of inflow total pressure and total temperature from the three profiles 


\section{ADPAC EEE LP Turbine Analysis}

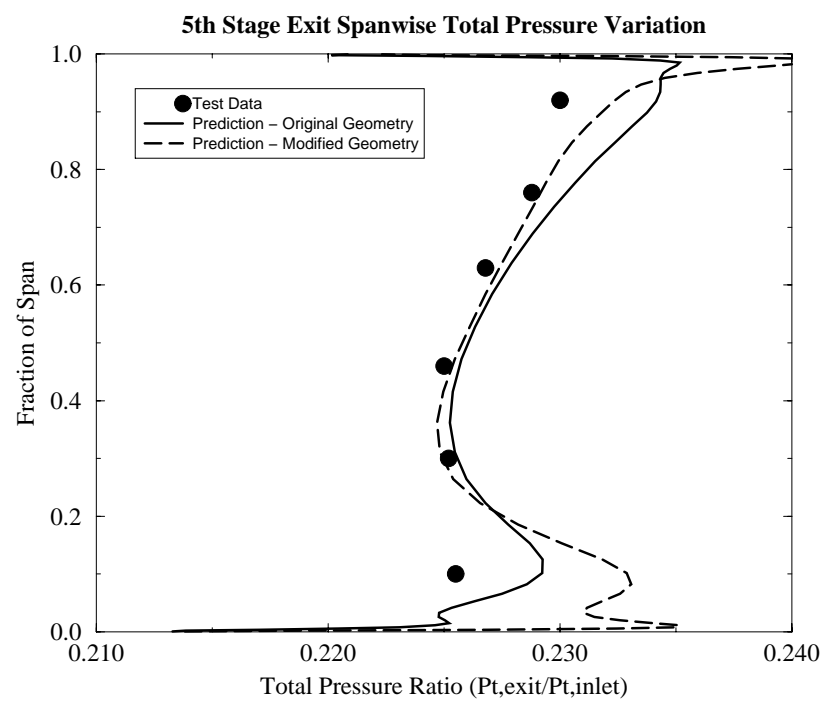

ADPAC EEE LP Turbine Analysis

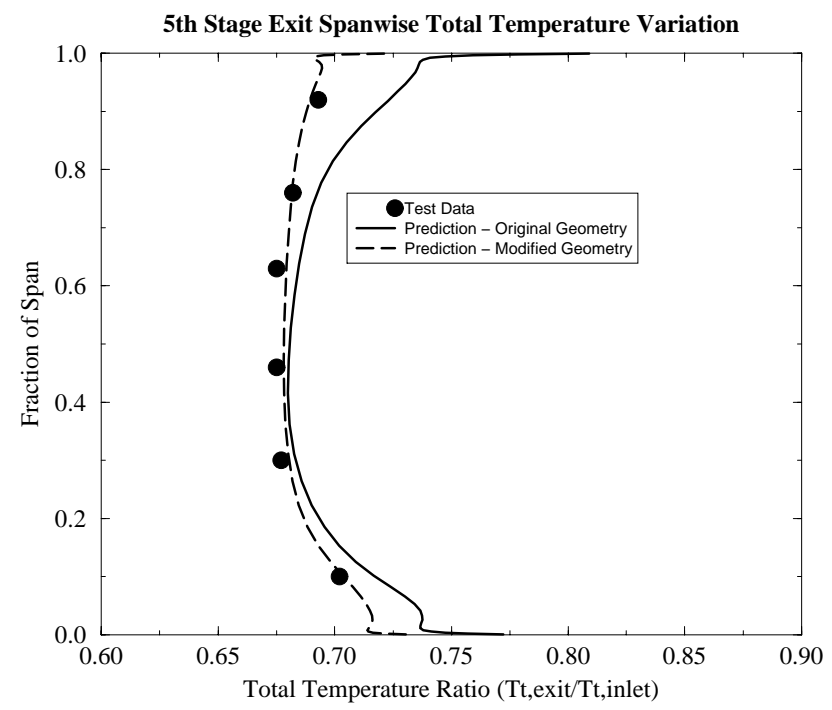

Fig. 10 Comparison of predicted and experimental spanwise variation in fifth stage exit total temperature distributions for EEE LP turbine analyses with variations in first vane reset and endwall modeling.

is given in Figure 11.

Figure 12 illustrates the comparison of predicted and expcrimental LP turbine exit spanwise total pressure and total temperature profiles for cach of the inlet profile variations described above. Note that there is not a significant change in the exit profile total pressure characteristics with variations in inlet profile specification. This is partially duc to the fact that cach calculation is run to the same cxit static pressure ratio. There is some variation in the exit total temperature distributions, although this behavior essentially correlates with the inlet total temperature profile charactcristics.
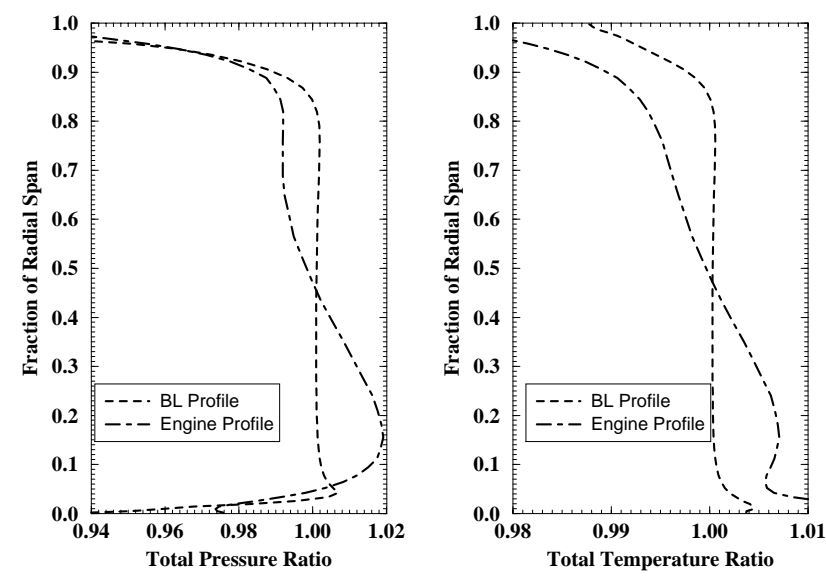

Fig. 11 Comparison of spanwise variation of inflow total pressure and total temperature ratio profiles for profiles for the EEE LP turbine analyses with variations in inlet profile.

\section{Effect of Variations in Endwall Geometry}

The final comparison of results involved discrete modeling of the turbine shrouded rotor scal cavitics. The calculations described above were all performed using a gcometry model based on a smooth, continuous cndwall definition. In reality, the cndwalls are quite discontinuous and irregular due to the use of shrouded rotors and overlapping geometry, and these irregularities can have a significant impact on the primary gas path flow. Previous expcricnce in predicting flows through compressor scal cavities suggests that the seal cavitics themselves can often be modeled using two-dimensional techniques, and then subsequently coupled with the 3-D blade passage flow through avcraging techniques similar to a mixing planc. This was the approach adopted in this study to minimize the computational effort involved with modeling this more complicated flow casc.

An illustration of the predicted axisymmetricaveraged Mach number contours for the EEE LP turbine with shrouded rotor cavity model is presented in Figure 13. The influcnce of the cavitics would appear to be limited to local regions along the case near the inflow/outflow openings of the cavity.

A summary of the ovcrall performance charactcristics duc to the variations described above is given in Table 1. In terms of overall performance, variations in inlet profilc did not appcar to have a significant cffect on the predicted mass flow rate, cxit total pressure, total tempcrature, or efficiency for the smooth endwall model. In the cavity endwall model calculations, the differences due to inlet profile were more pronounced. Variations in first vane reset primarily affected the predicted mass flow rate. The 1 degrec (open) reset of the first stage vane resulted in an increase in flow of $0.78 \%$ for the smooth endwall test case, and an increase of $1.59 \%$ for the cavity endwall model test casc. Finally, in terms of the cffects of variations in 
ADPAC EEE LP Turbine Analysis

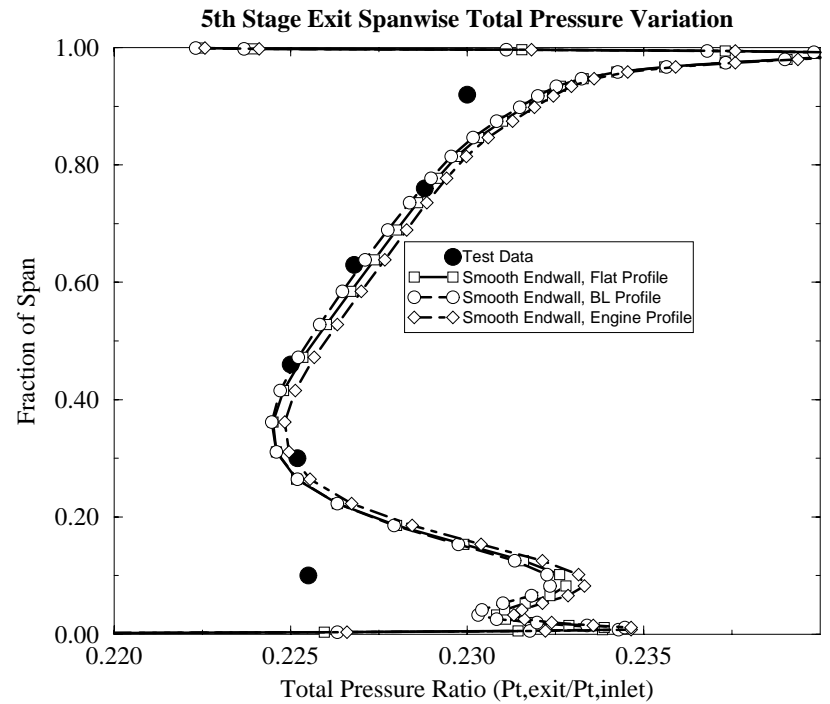

ADPAC EEE LP Turbine Analysis

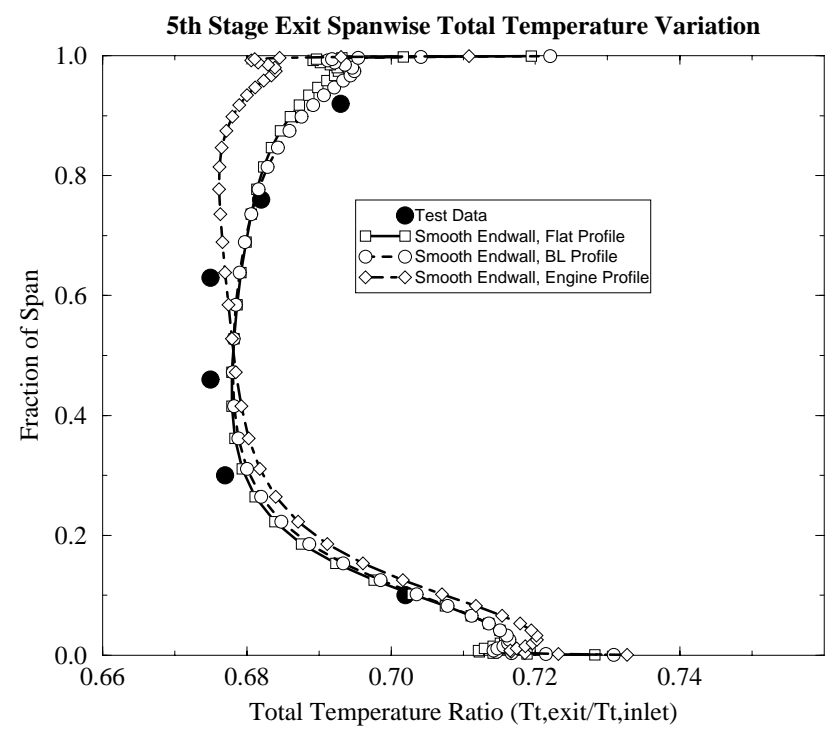

Fig. 12 Comparison of predicted and experimental spanwise variation in fifth stage exit total temperature distributions for EEE LP turbine analyses with variations in inlet profile.

the endwall model, the most prominent characteristics were reductions in predictcd mass flow ratc and adiabatic efficiency duc to the cavity endwall flow model. The reduction in cfficiency was quitc dramatic - on the order of $3 \%-5 \%$ depending on the test case. One problem cncountercd during this cvaluation was an inability to consistently maintain a constant mass flow from blade row to blade row in the cavity endwall solutions. Typical variations in mass flow from blade row to blade row in the multistage simulations using the smooth endwall model was $0.3 \%$, while the cavity cndwall model resulted in blade row to blade row variations as high as $2.0 \%$. The large variation in the cavity flow model was a result of the complicated mixing-

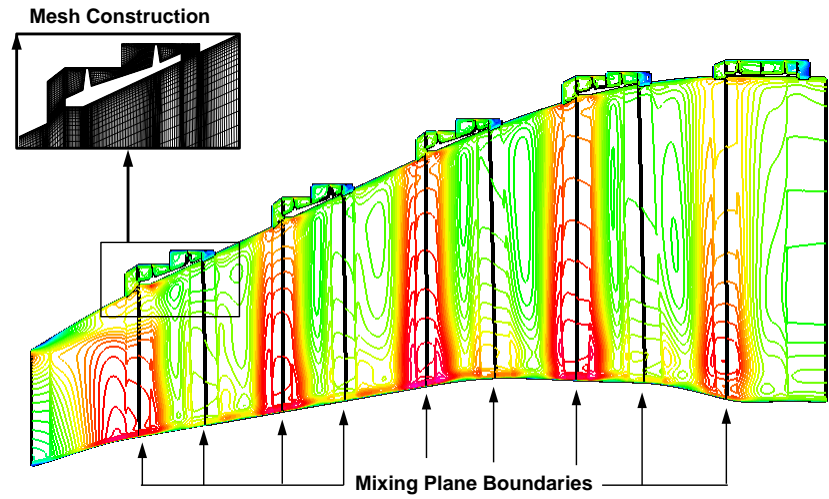

Fig. 13 Illustration of predicted axisymmetricaveraged Mach number contours for the EEE LP turbine with shrouded rotor cavity endwall model.

\begin{tabular}{|c|c|c|c|c|c|c|}
\hline $\begin{array}{l}\text { Inlet } \\
\text { Profile } \\
\text { Type }\end{array}$ & $\begin{array}{l}\text { First } \\
\text { Vane } \\
\text { Reset }\end{array}$ & $\begin{array}{l}\text { Endwall } \\
\text { Type }\end{array}$ & $\begin{array}{l}\text { Mass } \\
\text { Flow } \\
(\mathrm{lb} / \mathbf{s})\end{array}$ & $\begin{array}{l}\text { Pt, } \\
\text { Exit } \\
\text { (psia) }\end{array}$ & $\begin{array}{l}\text { Tt, } \\
\text { Exit } \\
\text { (deg. R) }\end{array}$ & $\begin{array}{l}\text { Adiabatic } \\
\text { Efficiency } \\
\text { (Mass-Avg.) }\end{array}$ \\
\hline $\begin{array}{l}\text { Flat } \\
\text { BL } \\
\text { Engine }\end{array}$ & $\begin{array}{l}0 \\
0 \\
0\end{array}$ & $\begin{array}{l}\text { Smooth } \\
\text { Smooth } \\
\text { Smooth }\end{array}$ & $\begin{array}{l}67.652 \\
67.366 \\
68.228\end{array}$ & $\begin{array}{l}10.299 \\
10.292 \\
10.314\end{array}$ & $\begin{array}{l}514.01 \\
514.49 \\
512.70\end{array}$ & $\begin{array}{l}91.72 \% \\
91.60 \% \\
91.99 \%\end{array}$ \\
\hline$B L$ & 1 open & Smooth & 67.896 & 10.308 & 514.57 & $91.64 \%$ \\
\hline $\begin{array}{l}\text { Flat } \\
\text { BL } \\
\mathrm{BL}\end{array}$ & $\begin{array}{l}0 \\
0 \\
1 \text { open }\end{array}$ & $\begin{array}{l}\text { Cavity } \\
\text { Cavity } \\
\text { Cavity }\end{array}$ & $\begin{array}{l}67.146 \\
66.705 \\
67.784\end{array}$ & $\begin{array}{l}10.304 \\
10.284 \\
10.316\end{array}$ & $\begin{array}{l}526.86 \\
522.92 \\
522.60\end{array}$ & $\begin{array}{l}86.74 \% \\
88.27 \% \\
88.53 \%\end{array}$ \\
\hline \multicolumn{7}{|c|}{$\begin{array}{l}\text { Notes: } \\
\text { 1. Nominal inlet total pressure }=45.0 \text { psia } \\
\text { 2. Nominal inlet total temperature }=750 \text { deg. } R \\
\text { 3. Approximate variation in computed mass flow from blade row to blade row: } \\
\qquad \text { Smooth Endwall: } 0.3 \%\end{array}$} \\
\hline
\end{tabular}

Table 1 Comparison of predicted overall performance parameters due to variations in inlet profile, endwall model, and first vane reset for the EEE LP turbine $2 / 3$ scale test rig.

plane arrangement employed to numerically couple the 2-D cavity passage openings with both the upstream and downstrcam neighboring blade row 3-D mesh systems. Given this large level of mass flow variation, the large predicted cfficiency reduction duc to the addition of the shrouded rotor cavities should be interpreted qualitativcly, not nccossarily quantitativcly

Off-design component performance $A D P A C$ solutions for the LP turbine were compared with GE scalcd test rig Block II, Configuration 5 experimental data. ${ }^{15}$ $A D P A C$ was employed to gencrate several operating point solutions near the design blade-jet specd ratio $\left(u / C_{o}=0.412\right.$ where $u$ is the turbine inlet mean axial vclocity and $C_{O}$ is the turbine tip specd) for the 2.4 million point LP mesh. The mesh included 2-D shrouded rotor scal gcometrics. A constant blado-jet specd ratio was set by fixing the inlet-to-cxit pressure ratio and solving for the necessary shaft rotational specd. Pressure ratios of 2.0, 3.0 and 4.76 wcre used for computations and ADPAC data was reduced to cnable comparison of cquivalcnt cncrgy cxtraction, inlet flow function, total-to-total cfficiency and totalto-static efficiency. The comparisons are displayed in Figures 14-17.

The predicted trends for equivalent energy extrac- 


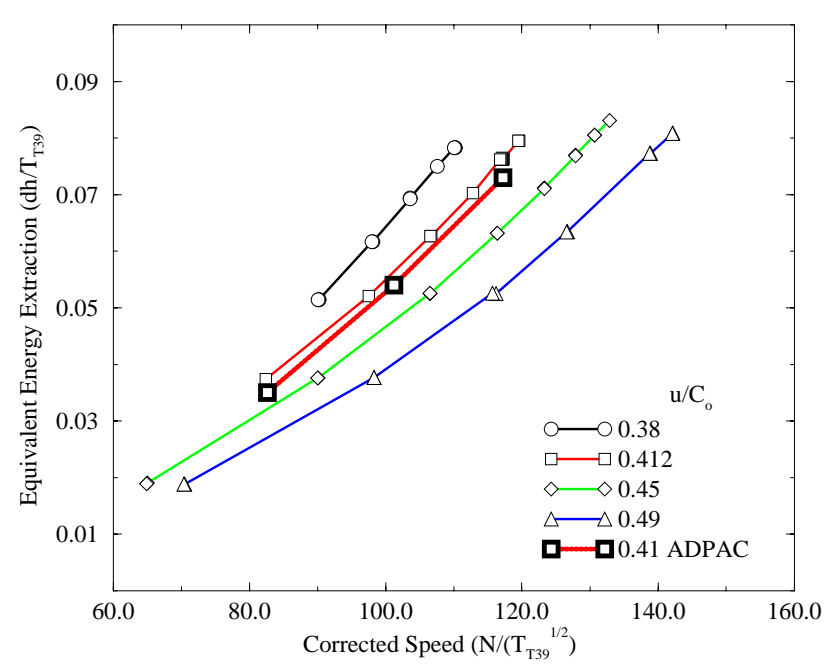

Fig. 14 Comparison of predicted (ADPAC) and measured equivalent energy extraction for the Energy Efficient Engine (EEE) LP turbine.

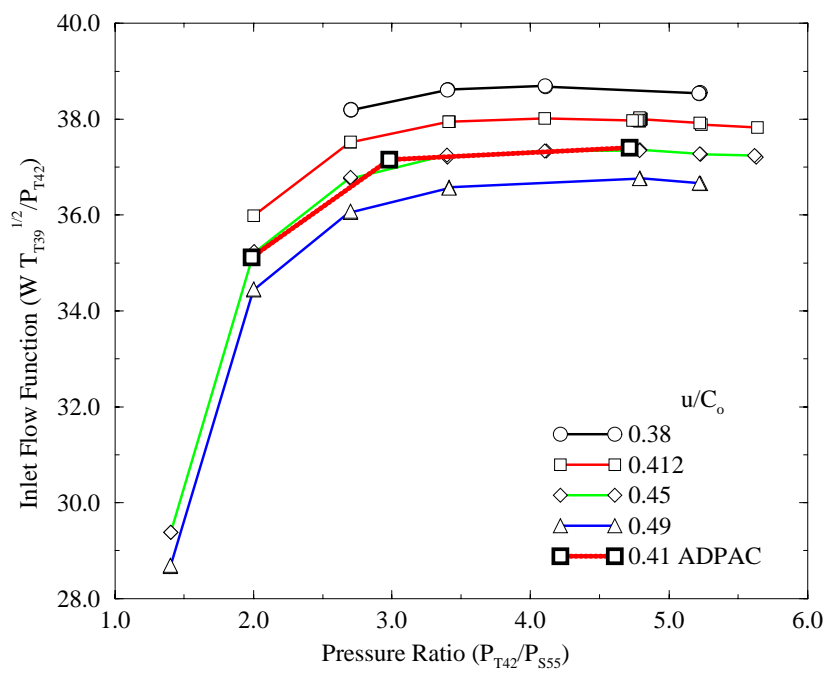

Fig. 15 Comparison of predicted (ADPAC) and measured inlet flow function for the Energy Efficient Engine (EEE) LP turbine.

tion and inlet flow function compare well with the scalcd rig test data. The absolute levels of these performance parameters is also predicted reasonably well, in spite of the numerous uncertainties concerning the test vchicle and the data reduction procodures. The predicted trends in efficiency were also captured reasonably well; however, the predicted efficiencics are consistently $2 \%-4 \%$ low. This difference was duc, in part, to the modcling of shrouded rotor scal flow, which caused a $3 \%-5 \%$ drop in adiabatic cfficiency when compared to the smooth endwall prediction. The discrepancy in cfficiency varicd considerably based on the numerical method used to compute the efficiency (total temperature, angular momentum change, mass avcraging versus arca avcraging, ctc.). The large number of unpublished features of the test rig operation, and the uncertainties associated with the numerical

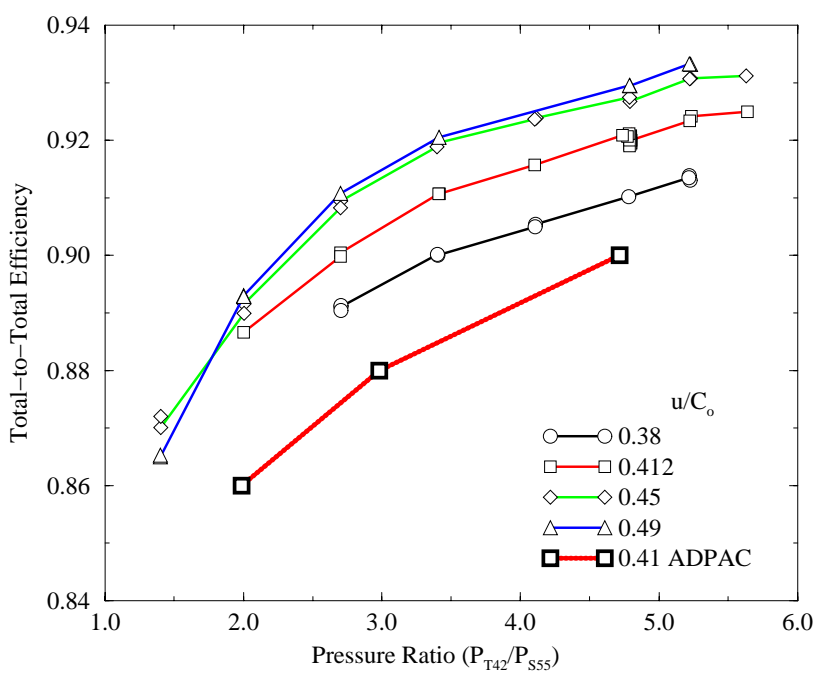

Fig. 16 Comparison of predicted (ADPAC) and measured total to total adiabatic efficiency for the Energy Efficient Engine (EEE) LP turbine.

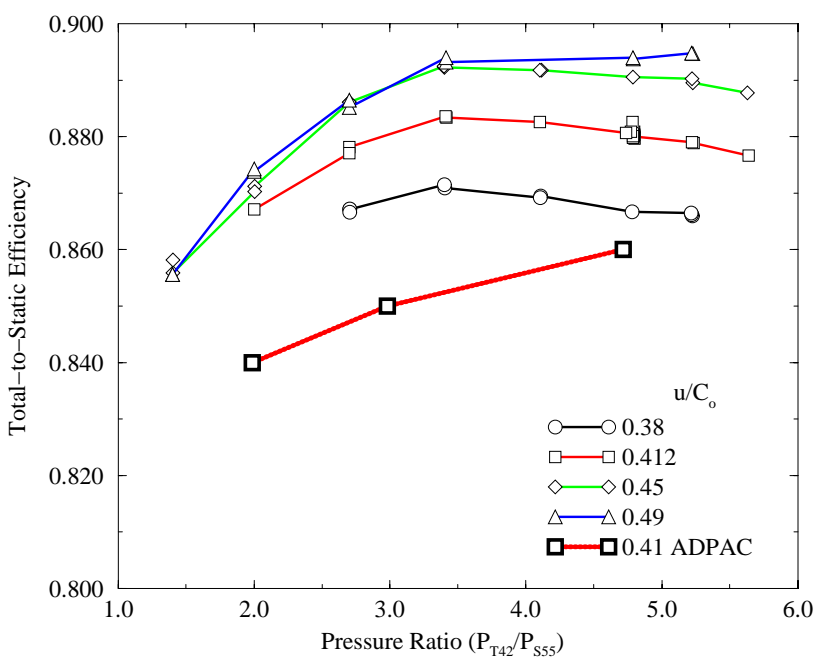

Fig. 17 Comparison of predicted (ADPAC) and measured total to static adiabatic efficiency for the Energy Efficient Engine (EEE) LP turbine.

cavity model prohibited timcly investigation of this discrepency.

\section{EEE Lobed Exhaust Mixer Analysis}

Static scale model tests were conducted to cvaluate cxhaust systcm mixcrs for a high bypass ratio cngine as part of the NASA sponsorcd Encrgy Efficicnt Engine Program. ${ }^{16}$ Gross thrust coefficients were measurcd for a scrics of mixcr configurations which included variations in the number of mixer lobes, tailpipe length, mixer penctration, and length. Mixer configuration variables included lobe number, penetration and perimeter, as well as scveral cutback mixer geometries. Mixing effectiveness and mixer pressure loss were determined using measurcd thrust and nozzlc exit total pressure and temperature surveys. These scaled results provided a data base to aid the anal- 

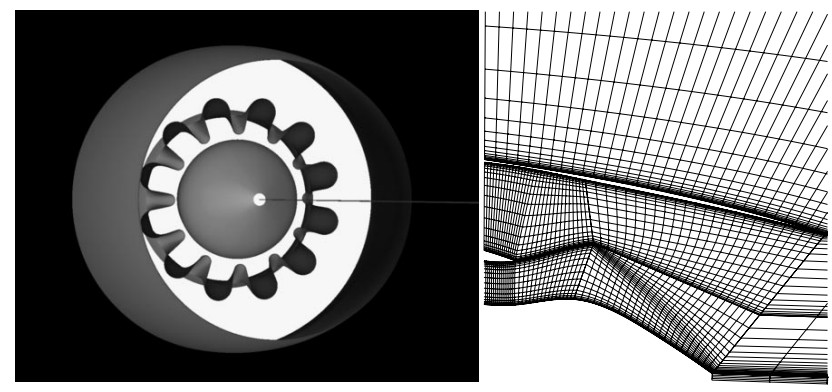

Fig. 18 Illustration of EEE lobed exhaust mixer geometric surfaces and symmetry plane mesh employed during the component validation study (analysis employs one lobe and assumes periodicity from lobe to lobe).

ysis and design/development of the EEE mixcd-flow cxhaust system. The final EEE Flight Propulsion Systcm (FPS) lobed cxhaust mixcr cmploycd a scalloped, 12-lobe design based on the results of the extensive rig testing.

Mesh gencration was performed using the GRID$G E N$ mesh gencration program. A partial geometry database was constructed by NASA during this study and was cmployed for the EEE LPS simulations doscribed in this section and the following chapter. The geometry is at least representative of the final design, but there remains some uncertainty as to the complete accuracy of the lobed surfaces. In addition, the actual test article employed scallops on the lobes to cnhance mixing. Since no detailed information on scallop configuration was available, the cut-outs were not modeled in this study. An illustration of the modeled surfaces of the EEE lobcd cxhaust mixcr is given in Figure 18. The EEE lobed cxhaust mixer mesh system along the lobe plane of symmetry is also given in Figure 18. A total of 9 mosh blocks were cmployed to define the coannular engine flow streams and the cxternal flow strcam. An illustration of the mesh systcm at the mixcr plane is given in Figure 18 as well.

A design flow analysis was performed for the EEE lobed exhaust mixer using the $A D P A C$ code. Results from the analysis were integrated and qualitativcly compared to the test data from the rig test study. ${ }^{16}$ Only a qualitative comparison was possible duc to uncertainty between the modeled mixer and the geometries described in the rig tests.

Spanwise total temperature profiles at the mixcr/nozzle cxit are illustrated in Figure 19. Predicted and expcrimental total temperature ratios are plotted against a normalized nozzle arca distribution along scveral circumferentially spaced arrays spanning a single half-lobe of the mixer. The test data was derived from a study ${ }^{16}$ of mixcr configurations of varying penctration, arca ratio, ctc. To validate the mixer predictions, test data was derived from an esscntially cquivalent mixcr (Configuration F3,
12 lobes, 39\% penctration) which was tested under the referenced study. In gencral, the spanwise charactcristics of the mixer are qualitativcly captured, particularly along the lobe radial peak (Station A on Figure 19 survey. There is some noticcable disagrecment between prediction and test at survey Stations D and E. This discrepency is likely due to the fact that the numerical and test mixer geometries wcre not cxactly similar, and also duc to the gencrally accepted obscrvation that the algebraic turbulence model cmployed in the present analyses is not woll suited for temperature mixing problems of this sort.

\section{EEE LP Subsystem Analysis}

This section deals with the results of numerical modeling of the Low Pressure (LP) Subsystem of the Gencral Elcctric (GE) Encrgy Efficicnt Engine (EEE). Grid generation for the EEE LP subsystem analysis was based essentially on collecting the individual meshes for the major subcomponents (fan, HP/LP turbines and lobed mixcr) employed during the component validation study. The existing fan, quartcr-hcight booster stage, HP turbine, LP turbine, and lobed mixer subsystem component meshes were asscmbled for this purpose. In addition, now meshes were gencrated using GRIDGEN to model those regions which were not discretized by any of the component validation models. These new regions included the forwardmost flow in the inlet, external flow about the nacelle, and the bypass duct flow between the fan section bypass vane and the lobed exhaust mixer. For computational simplicity, these now regions were modeled in a two-dimensional fashion (the analysis is cortainly not limited in this respect), and were computational coupled to the threc-dimensional domains using the $A D P A C$ mixing plane strategy (sce c.g. Figure 20). It should be cmphasized that all primary components (blade rows, for example) were still modeled with 3D mesh systems. The collection and assembly of these meshes resulted in a numcrical model of the entire EEE (minus the engine core compressor and combustor). It should be noted that although the high pressure compressor and combustor were not discretcly modeled, the influences of these components were approximated by cquivalent inflow and outflow boundary conditions. Figure 20 illustrates axisymmetric projections of the resulting EEE mosh/gcometry model. The resulting primary mesh for the EEE LP analysis consisted of 74 scparatc blocks and approximatcly 6.7 million grid points.

All calculations for the EEE LP Subsystem wore performed on parallel computing systems. Timing comparisons for the various computational platforms cmployed in this study for the EEE LP Subsystem analysis are provided in Table 2 .

Overall, the following comments can be made concorning the parallel performance studics: 

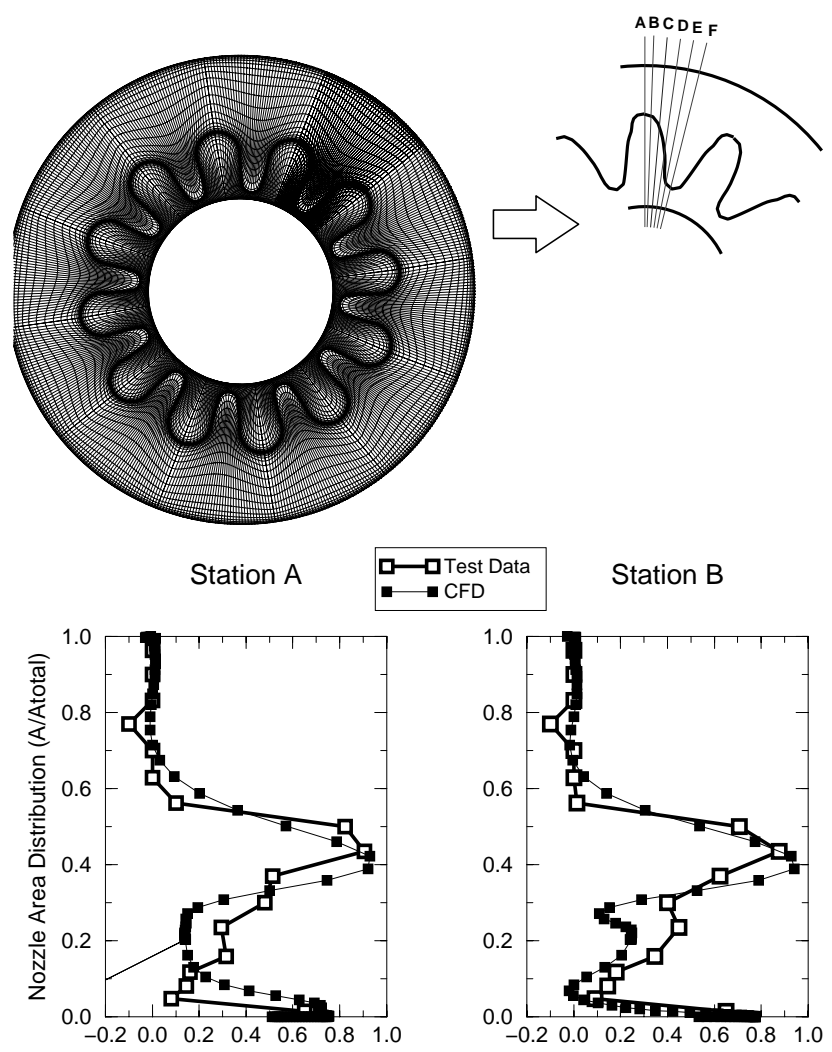

$\longrightarrow$ CFD

Station B

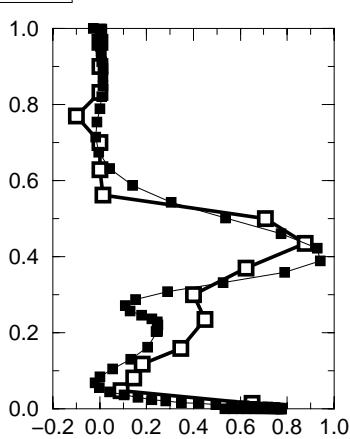

Station C

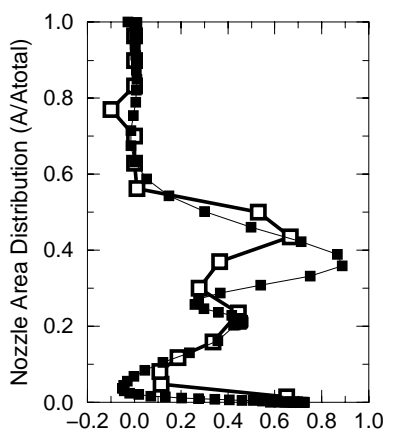

Station $\mathrm{E}$

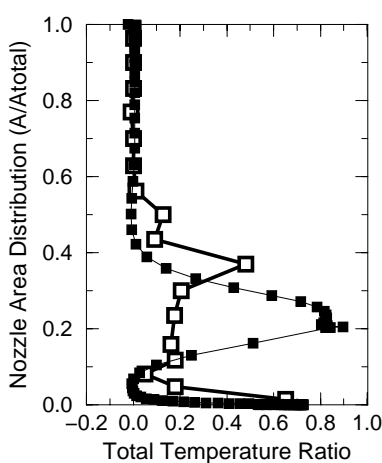

Fig. 19 Comparison of predicted and experimental radial total temperature surveys for the EEE lobed exhaust mixer.

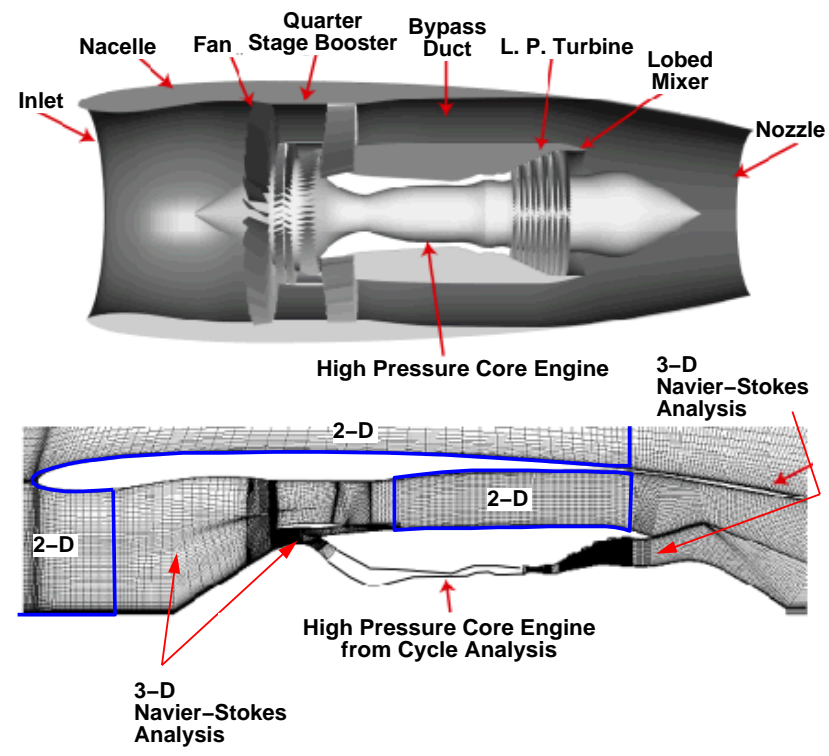

Fig. 20 Axisymmetric projection of Energy Efficient Engine (EEE) Low Pressure (LP) Subsystem analysis component layout and mesh system.

\begin{tabular}{|c|c|c|c|c|c|c|}
\hline \multirow[b]{3}{*}{ LACE } & \multicolumn{6}{|c|}{$\begin{array}{l}\text { Wall Clock Time Summary } \\
\text { (100 Iterations of EEE/LP Model) }\end{array}$} \\
\hline & \multicolumn{3}{|c|}{$\begin{array}{c}\text { Coarse Mesh } \\
\text { Number of Processors }\end{array}$} & \multicolumn{3}{|c|}{$\begin{array}{l}\text { Fine Mesh } \\
\text { Number of Processors }\end{array}$} \\
\hline & 8 & 16 & 32 & 8 & 16 & 32 \\
\hline $\begin{array}{l}\text { communication } \\
\text { cotal solver time }\end{array}$ & $\begin{array}{l}5380 \\
7762\end{array}$ & $\begin{array}{l}2139 \\
4846\end{array}$ & $\begin{array}{l}2707 \\
4198\end{array}$ & $\begin{array}{l}\text { N/A } \\
\text { N/A }\end{array}$ & $\begin{array}{l}23063 \\
77427\end{array}$ & $\overline{-}$ \\
\hline $\begin{array}{l}\text { Babbage } \\
\text { communication } \\
\text { total solver time }\end{array}$ & $\begin{array}{l}952 \\
2673\end{array}$ & $\begin{array}{l}403 \\
1418\end{array}$ & $\begin{array}{l}735 \\
1089\end{array}$ & $\overline{-}$ & - & $\begin{array}{l}8763 \\
17518\end{array}$ \\
\hline $\begin{array}{l}\text { Davinci } \\
\text { communication } \\
\text { total solver time }\end{array}$ & $\overline{-}$ & $\overline{-}$ & $\overline{-}$ & $\begin{array}{l}4617 \\
18122\end{array}$ & $\overline{-}$ & $\overline{-}$ \\
\hline $\begin{array}{l}\text { Allison SGI } \\
\text { Power Challenge } \\
\text { communication } \\
\text { total solver time }\end{array}$ & $\begin{array}{l}585 \\
1278\end{array}$ & $\begin{array}{l}182 \\
673\end{array}$ & $\begin{array}{l}\text { N/A } \\
\text { N/A }\end{array}$ & $\begin{array}{l}\mathbf{N} / \mathbf{A} \\
\mathbf{N} / \mathbf{A}\end{array}$ & $\begin{array}{l}\text { N/A } \\
\text { N/A }\end{array}$ & $\begin{array}{l}\text { N/A } \\
\text { N/A }\end{array}$ \\
\hline $\begin{array}{l}\text { Silicon Graphics } \\
\text { Origin 2000 } \\
\text { communication } \\
\text { total solver time }\end{array}$ & $\begin{array}{l}268 \\
781\end{array}$ & $\begin{array}{l}153 \\
403\end{array}$ & $\begin{array}{l}264 \\
327\end{array}$ & $\overline{-}$ & $\overline{-}$ & $\begin{array}{l}3105 \\
5528\end{array}$ \\
\hline $\begin{array}{l}\text { N/A - not applicable (m } \\
\text { LACE: NASA Lew } \\
\text { BABBAGE:NASA Ame } \\
\text { Davinci: NASA Ame }\end{array}$ & $\begin{array}{l}\text { ithine I } \\
\text { IBM I } \\
\text { IBM S } \\
\text { SGI cl }\end{array}$ & uster & & & & \\
\hline
\end{tabular}

Table 2 Tabulation of parallel computing CPU time estimates for platforms employed for the EEE LP Subsystem analysis (all times given are wall clock time on non-dedicated systems with precautions taken to eliminate outside loading factors).

- Pcak processing spced was achicved on a Silicon Graphics Origin 2000 using the SGI MPI 3.0 communication library.

- Estimated turnaround time for a single operating point was estimated to be 10 hours on the SGI Origin 2000 system using 32 processors.

- Load balance was non-optimal for the present mesh configuration. It scems cntircly possible that significant improvements in parallel computing efficiency might be achicved through a more 
structured specification of mesh block dimcnsions in the overall problem.

- For the faster systcms, parallel computing cfficicncy was still ncarly lincar with the addition of more processors. This implies that the problcm could still be effectively acclcrated if systems with larger numbers of processors $(>100)$ were available.

The boundary specifications for the EEE LPS analysis were bascd on a design point engine cycle analysis derived from results from the NEPP computer code. Note that for this set of results, the HP turbine (normally considered a core, or HP subsystem component) was cmployed in the CFD model to permit a more reasonable specification of the spanwise flow profiles cntering the LP turbine. Subscquent large-scale simulations of the LP Subsystcm did not cmploy the CFD representation of the HP turbine as it was ultimately demonstrated that the LP turbine performance is relatively insensitive to inlet flow profile.

\section{EEE LPS Shaft Power Balance}

An important aspect of cngine simulation, compared to component simulation, is that the mating of components often involves both acrodynamic and mechanical couplings. This concept is illustratcd for both singlcspool and twin-spool gas turbine engines in Figure 21. This concept is commonly cmployed in cycle dock analyses (c.g. NEPP) for components connected by a common shaft. The same concept can be applicd to larger-scale simulations by providing the appropriate acrodynamic consistency between components (mass flow, ctc.) as well as cquating the overall power requircments for common shaft-mounted components. This balance was iteratively achicved in the present simulation through an itcrative proccdure which cmployed shaft rotational speed as the means of achicving the desired shaft power balance.

A scrics of solutions for the EEE/LP Subsystcm was obtained for fixcd shaft rotational specds. For cach shaft specd, computed power and torque for the rotating components were integrated for the rotating components of both the LP turbine and fan/boosterstage asscmblics. Differences between the computed power/torque requirements for the fan and LP turbine asscmblics were then cmployed to estimate a new shaft specd for the subscquent solution. Simple physical rcasoning suggests that if there is power cxcoss, then the shaft specd should increase, and if there is a power deficit, then the shaft speed should decrease. A simple lincar interpolation was cmployed to estimate the updated shaft specd based on the integrated results from two previous solutions.

A portion of the itcrative history of the ADPAC EEE LP shaft power balance is given in Table 3. As the shaft specd was reduced, the power required by the
Aero-Mechanical Coupling in a Single Spool Gas Turbine

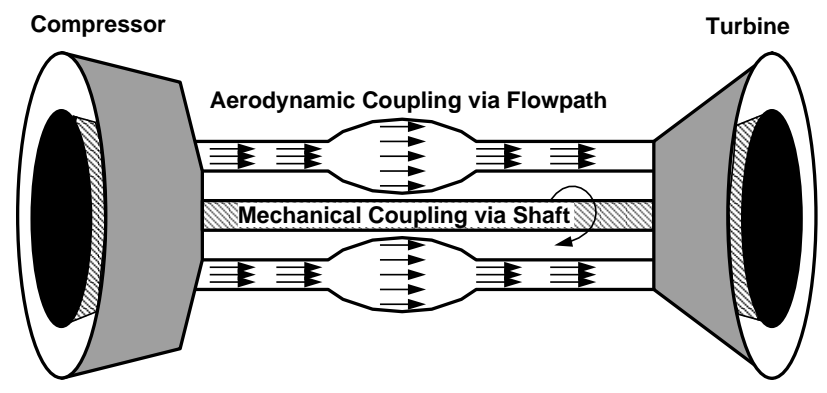

Aero-Mechanical Coupling in a Dual Spool Gas Turbine

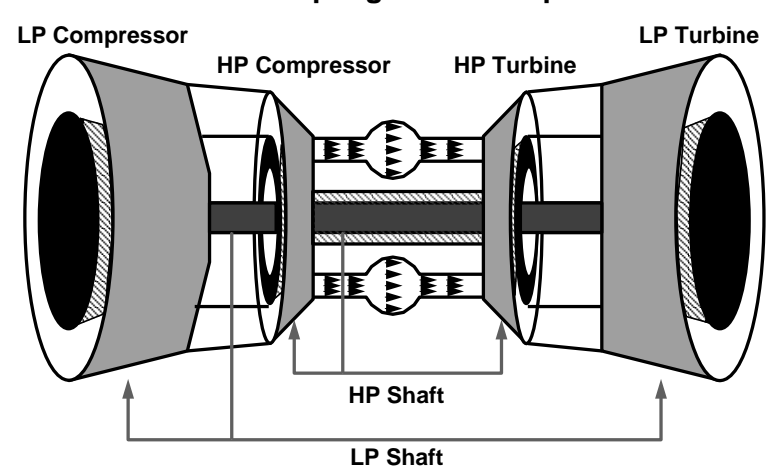

Mechanical Coupling via Shafts (Separately for LP/HP) Aerodynamic Coupling via Flowpath (Joint LP/HP)

Fig. 21 Illustration of aerodynamic/mechanical balance required for single-spool and twin-spool gas turbine engines.

fan was reduced, while the power provided by the LP turbine increased. Eventually, these two power levels were essentially identical. The balance was decmed converged when the power balance was within $1 \%$. Note that in spite of the changes to the LP system, the HP turbine power was relatively constant. This is essentially a result of the fact that the core performance was fixed during the shaft power balance procodure. The absolute power levels must be interpreted with the limitations of the CFD analysis in mind. The analysis was performed with a constant specific heat, when in fact, given the range of temperatures in the machine, the specific heat actually varies up to $5 \%$. In addition, parasitic losses in the compressor (cndwall leakages, cavity flows, ctc.) have not becn included in the analysis. The shaft power balance also assumes a $100 \%$ transmission cfficiency (no bearing losses).

\section{Core Cycle Boundary Specification}

Following the completion of the effort to develop an LP Subsystem shaft power balance computational procedure, the logical next step in the LP Subsystcm analysis was to couple the 3-D ADPAC predictions with a lower order (cycle deck) analysis of the core component performance. This coupling is consistent with the "zooming" philosophy inherent in the NPSS 
ADPAC Solution (Fixed RPM/Fixed Core, $\mathrm{ft}-\mathrm{lbf} / \mathrm{sec}$ )

\begin{tabular}{llcl} 
Shaft RPM & Fan & LP Turbine & HP Turbine \\
3507 & $8,622,000$ & $6,947,200$ & $12,634,000$ \\
3407 & $8,028,000$ & $7,002,600$ & $12,619,000$ \\
3250 & $7,522,300$ & $7,301,400$ & $12,557,000$ \\
3200 & $7,243,100$ & $7,322,700$ & $12,547,000$ \\
& & & \\
\multicolumn{4}{c}{ NEPP Solution (Design Point) } \\
Shaft RPM & Fan & LP Turbine & HP Turbine \\
3538.5 & $8,182,000$ & $8,182,000$ & $11,625,300$
\end{tabular}

Table 3 Tabulation of coarse mesh EEE LP Subsystem shaft power balance iterative results.

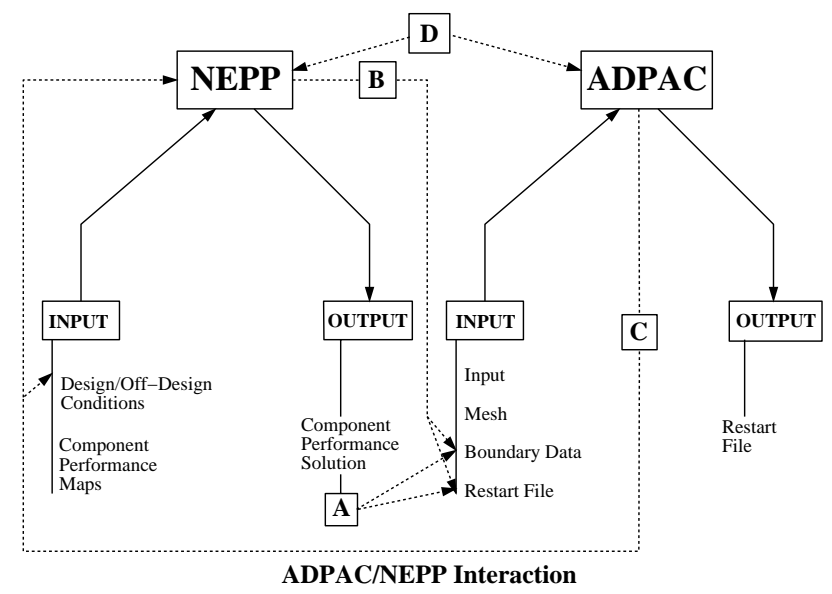

A. Use NEPP output to create ADPAC Boundata and Restart files 1. No direct link between NEPP and APAC

2. NEPP output file updates EXIT and INLET conditions and RPM boundata file

3. NEPP output file creates ADPAC restart file to aid in "start-up" process

B. Create coding changes in NEPP to perform A

C. Use SYSTEM call in ADPAC boundata file to run NEPP from ADPAC

D. Use front-end script to control NEPP-ADPAC interations

Fig. 22 Coupled ADPAC/NEPP analysis schematic data flow representation.

system architecture. In the present application, the core cycle model was bascd on predictions from the $N E P P$ code. In order to incorporate the NEPP results in a systcmatic fashion, the various interactions between the NEPP core model and the ADPAC LP Subsystem model must be addressed. One interpretation of these interactions is outlined schematically in Figure 22. The spccifications requircd from NEPP for the ADPAC analysis are an estimate of the core compressor inlet flow (representcd initially by a static pressure which is used to set the flow in the ADPAC solution), and a spccification of the HP turbine inlet total pressure and total temperature profiles describing the flow out of the EEE combustor. The specifications required from the ADPAC analysis for the NEPP analysis include the core compressor inlet total pressures, temperature and velocities (which result from the CFD analysis of the fan section). Intertwined in this cross specification is the fact that the LP shaft RPM may change as the ovcrall solution cvolves, and the level and frequency by which the exchanged boundary data betwecn the two analyses occurs may be critical.

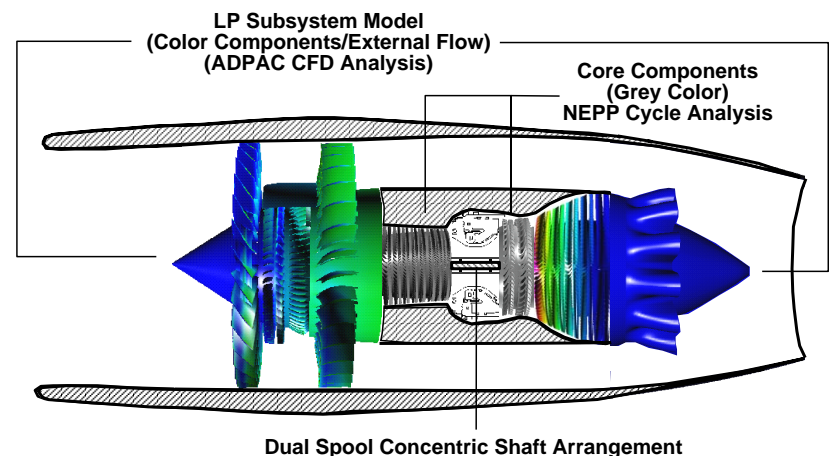

Fig. 23 Illustration of coupled ADPAC/NEPP prediction for the EEE LP Subsystem (color contours indicate predicted static pressure ratio: red10.0, blue-0.36, grey scale components are represented by the NEPP cycle analysis).

The computational system resulting from the combined $N E P P / A D P A C$ computational procedure is illustrated graphically in Figure 23. Since this procedure was designed for demonstration purposes, the coupling between the $A D P A C$ and $N E P P$ analyses was controlled by a UNIX shell script which scquentially applicd the analyses in an itcrative fashion. Following the application of cach analyses, the appropriatc flow information was extracted from output files by hardwired programs devcloped specifically for these two codes, and bascd specifically on the format of the output for cach codes. This was, unfortunatcly an inflexible system, but did have the advantage that it could be assembled rather quickly to demonstrate the ovcrall concept.

A solution for the EEE/LP Subsystem using the coupled ADPAC/NEPP solution strategy was obtained for the design opcrating point. Problems cncountered during the initial tests of the solution procedure were traced to excessive variations in the boundary specifications during the initial phases of the calculations. These excursions were modulated using a simple under-rclaxation procedurc. The behavior of the ovcrall solution procedure was then relatively stable, albcit very slow. Individual $A D P A C$ solutions acquired during the itcrative cycle can take up to 8 hours on a parallel system, with some 10-20 itcrations required to achicve complete coupling between the ADPAC and NEPP analyses.

It should be noted that the present demonstration did not cmploy the LP shaft power balance procedure which would be essential to complete the coupled solution proccdure. At this point, a demonstration of the concept was considered of primary importance. The capability demonstrated through this excrcisc validates the NPSS primary objective of "zooming", and can hopcfully lead to further rescarch in cmploying this type of analysis for future gas turbine engine studies. 


\section{Concluding Remarks}

Computational Fluid Dynamics (CFD) analysis of the complete Low Pressure (LP) Subsystem of the General Electric Encrgy Efficient Engine (EEE) was demonstrated. This study identificd scveral important topical arcas to consider in the planning and execution of large-scalc simulations of complete gas turbine cngine propulsion systems. The topical arcas include gcometry manipulation, mesh gencration, solution initialization, application of parallcl computing, full-scalc cngine simulation, and interpretation of computational results. Detailed analysis of the procedures and predicted results yiclded the following considerations:

- Some form of gcometry manipulation is essential to permit rcalistic representation of industry gas turbine engine designs

- The effects of sccondary flow systems (lcakage paths, cooling flows, ctc.) on primary gas flowpath performance are significant and require further modeling rescarch to permit valid simulations of engine cnvironment flows.

- Improvements to the mixing plane solution stratcgy (addition of detcrministic stresses, nonreflecting procedures) may aid convergence and solution integrity.

- Access to larger scale (>32 processors) parallel cluster systems would permit more rapid analysis.

\section{Acknowledgements}

The work described in this paper was supported under the NASA High Pcrformance Computing and Communication Program (HPCCP), contract NAS327394, Task 13.

\section{References}

${ }^{1}$ Tagan, J. R. and Hall, E. J., "Yixing Mechanisms in Multistage Compressors," Advanced Turbomachinery Design, 1997.

${ }^{2}$ Ilall, E. J., "Aerodynamic Modeling of Multistage Compressor F lowfields-Part 1: Analysis of Rotor/Stator/Rotor Aerodynamic Interaction," ASME Paper 97-GT-341, Jun. 1997.

${ }^{3}$ Hall, E. J., "Aerodynamic Modeling of Multistage Compressor Flowfields-Part 2: Modeling Deterministic Stresses," ASWE Paper 97-GT-345, Jun. 1997.

${ }^{4}$ Klann, J. L. and Snyder, C. A., "XEPP Programmers Manual (XASA Engine Performance Program) Volume 1. Technical Description," NASA TM 106575, Sep. 1994.

${ }^{5}$ Barber, T., Choi, T., McNulty, G., Hall, E., and Delaney, R., "Preliminary Findings in Certification of ADPAC," AIAA Paper 94-2240, Jun. 1994.

${ }^{6}$ IIall, E. J. and Delaney, R. A., "Investigation of Advanced Counterrotation Blade Configuration Concepts for High Speed Turboprop Systems: Task VII - ADPAC Lser's Manual," NASA CR 195472, Jul. 1995.

${ }^{7}$ Jameson, A., Schmidt, W., and Turkel, E., "Yumerical Solutions of the Euler Equations by Finite Volume Methods Lsing Runge-Kutta Time-Stepping Schemes," AIAA Paper 81-1259, 1981.
${ }^{8}$ Adamczyk, J. J., Celestina, M. L., and Beach, T. A., "Simulation of Three-Dimensional Viscous Flow Within a Multistage Turbine," AS.IE Paper 89-GT-152, 1989.

${ }^{9}$ Arnone, A. A., Liou, M. S., and Povinelli, L. A., "Vultigrid Time-Accurate Integration of Navier-Stokes Equations," AIAA Paper 93-3361-CP, 1993.

${ }^{10}$ Baldwin, B. S. and Lomax, H., "Thin Layer Approximation and Algebraic Model for Separated Turbulent Flows," AIAA Paper 78-257, 1978.

11 "YPI: A Message-Passing Interface Standard," International Journal of Supercompuling Applicalions, Vol. 8 , No. $3 / 4$ 1994.

${ }^{12}$ et. âl., J. S., "The Gridgen 3D Multiple Block Grid Generation System." Final Report WRDC-TR-90-3022, Jun. 1990.

${ }^{13}$ Anderson, D. A., Tannehill, J. C., and Pletcher, R. II., Compulalional Fluid Mechanics and IIcal Transfer, 1981.

${ }^{14}$ Cline, S. J., Halter, P. II., Kutney, J. T., and Sullivan, T. J., "Energy Efficient Engine: Fan and Quarter-Stage Component Performance Report," NASA CR 168070, Jan. 1983.

${ }^{15}$ Bridgeman, M. J., Cherry, D. G., and Pedersen, J., "XASA/GE Energy Efficient Engine Low Pressure Turbine Scaled Test Vehicle Performance Report," XASA CR 168290, Jul. 1983.

${ }^{16}$ Rowe, R. K. and Kuchar, A. P., "Energy Efficient Engine $\left(E^{3}\right)$ Scaled Mixer Performance Report - Final Report," XASA CR 167947, Nov. 1982 


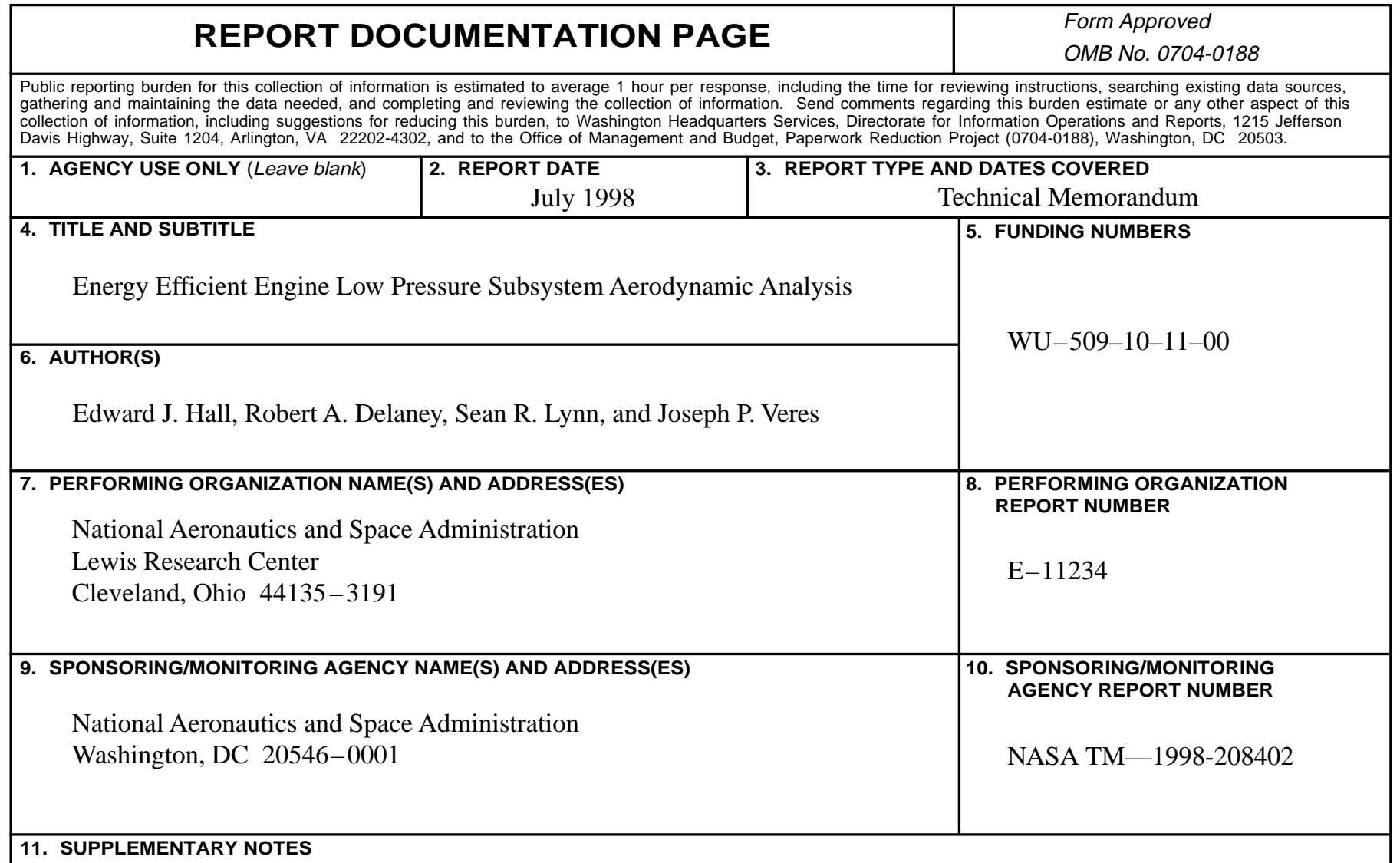

Prepared for the 34th Joint Propulsion Conference and Exhibit cosponsored by AIAA, ASME, SAE, and ASEE, Cleveland, Ohio, July 13-15, 1998. Edward J. Hall, Robert A. Delaney, and Sean R. Lynn, Allison Engine Company, Indianapolis, Indiana 46241; Joseph P. Veres, NASA Lewis Research Center. Responsible person, Joseph P. Veres, organization code 2900, (216) 433-2436.

\begin{tabular}{|l|l|}
\hline 12a. DISTRIBUTION/AVAILABILITY STATEMENT & 12b. DISTRIBUTION CODE
\end{tabular}

Unclassified - Unlimited

Subject Categories: 07 and $02 \quad$ Distribution: Nonstandard

This publication is available from the NASA Center for AeroSpace Information, (301) 621-0390.

\section{ABSTRACT (Maximum 200 words)}

The objective of this study was to demonstrate the capability to analyze the aerodynamic performance of the complete low pressure subsystem (LPS) of the Energy Efficient Engine (EEE). Detailed analyses were performed using threedimensional Navier-Stokes numerical models employing advanced clustered processor computing platforms. The analysis evaluates the impact of steady aerodynamic interaction effects between the components of the LPS at design and offdesign operating conditions. Mechanical coupling is provided by adjusting the rotational speed of common shaft-mounted components until a power balance is achieved. The Navier-Stokes modeling of the complete low pressure subsystem provides critical knowledge of component aero/mechanical interactions that previously were unknown to the designer until after hardware testing.

\begin{tabular}{|c|c|c|c|}
\hline \multirow{3}{*}{\multicolumn{3}{|c|}{$\begin{array}{l}\text { 14. SUBJECT TERMS } \\
\text { System model; Computer simulation; CFD; Turbofan engine; Flow; Performance; } \\
\text { Aerodynamics }\end{array}$}} & \multirow{3}{*}{\begin{tabular}{|c|} 
15. NUMBER OF PAGES \\
22 \\
16. PRICE CODE \\
A03 \\
\end{tabular}} \\
\hline & & & \\
\hline & & & \\
\hline Unclassified & Unclassified & Unclassified & \\
\hline
\end{tabular}

